UNIVERSITE DE NICE COTE D'AZUR

FACULTE DE MEDECINE DE NICE

THESE D’EXERCICE DE MEDECINE

En vue de l'obtention du

DIPLOME D’ETAT DE DOCTEUR EN MEDECINE

Spécialité : HEMATOLOGIE CLINIQUE

Présentée et soutenue publiquement à la Faculté de Médecine de Nice

Le mercredi 20 mai 2020

Par

Clémence MARCAULT

Née le 10 août 1991, à Montpellier (34)

ALTERNATIVE EFFECTIVE AND SAFE INDUCTION REGIMENS FOR NEWLY DIAGNOSED ACUTE MYELOID LEUKEMIA IN PATIENTS WITH CARDIAC CONTRA-INDICATION TO ANTHRACYCLINES

Jury :

Président du jury : Madame le Pr Sophie RAYNAUD

Membres du jury : Monsieur le Pr Pierre-Simon ROHRLICH

Madame le Dr Karine RISSO

Monsieur le Dr Michaël LOSCHI

Directeur de thèse : Monsieur le Pr Thomas CLUZEAU. 
UNIVERSITE DE NICE COTE D'AZUR

FACULTE DE MEDECINE DE NICE

THESE D’EXERCICE DE MEDECINE

En vue de l'obtention du

DIPLOME D’ETAT DE DOCTEUR EN MEDECINE

Spécialité : HEMATOLOGIE CLINIQUE

Présentée et soutenue publiquement à la Faculté de Médecine de Nice

Le mercredi 20 mai 2020

Par

Clémence MARCAULT

Née le 10 août 1991, à Montpellier (34)

Jury :

Président du jury : Madame le Pr Sophie RAYNAUD

Membres du jury : Monsieur le Pr Pierre-Simon ROHRLICH

Madame le Dr Karine RISSO

Monsieur le Dr Michaël LOSCHI

Directeur de thèse : Monsieur le Pr Thomas CLUZEAU. 
A LA FACULTE DE MEDECINE DE NICE

\section{Doyen}

Pr. BAQUÉ Patrick

\section{Vice-doyens}

Pédagogie

Pr. ALUNNI Véronique

Recherche

Pr DELLAMONICA jean

Etudiants

M. JOUAN Robin

Chargé de mission projet Campus

Pr. PAQUIS Philippe

Conservateur de la bibliothèque

Mme AMSELLE Danièle

Directrice administrative des services

Mme CALLEA Isabelle

Doyens Honoraires

M. RAMPAL Patrick

M. BENCHIMOL Daniel

\section{PROFESSEURS CLASSE EXCEPTIONNELLE}

M. BAQUÉ Patrick Anatomie - Chirurgie Générale (42.01)

M. BERNARDIN Gilles Réanimation Médicale (48.02)

Mme BLANC-PEDEUTOUR Florence Cancérologie - Génétique (47.02)

M. BOILEAU Pascal Chirurgie Orthopédique et Traumatologique (50.02)

M. DARCOURT Jacques Biophysique et Médecine Nucléaire (43.01)

M. DRICI Milou-Daniel Pharmacologie Clinique (48.03)

M. ESNAULT Vincent Néphrologie (52-03)

M. FUZIBET Jean-Gabriel Médecine Interne (53.01)

M. GILSON Éric Biologie Cellulaire (44.03)

M. GUGENHEIM Jean Chirurgie Digestive (52.02)

M. HASSEN KHODJA Reda Chirurgie Vasculaire (51.04)

M. HÉBUTERNE Xavier Nutrition (44.04)

M. HOFMAN Paul Anatomie et Cytologie Pathologiques (42.03)

Mme ICHAI Carole Anesthésiologie et Réanimation Chirurgicale (48.01)

M. LACOUR Jean-Philippe Dermato-Vénéréologie (50.03)

M. LEFTHERIOTIS Georges Chirurgie vasculaire ; médecine vasculaire (51.04)

M. MARQUETTE Charles-Hugo Pneumologie (51.01) 
M. MARTY Pierre Parasitologie et Mycologie (45.02)

M. MICHIELS Jean-François Anatomie et Cytologie Pathologiques (42.03)

M. MOUROUX Jérôme Chirurgie Thoracique et Cardiovasculaire (51.03)

Mme PAQUIS Véronique Génétique (47.04)

M. PAQUIS Philippe Neurochirurgie (49.02)

M. PRADIER Christian Épidémiologie, Économie de la Santé et Prévention (46.01)

M. QUATREHOMME Gérald Médecine Légale et Droit de la Santé (46.03)

M. RAUCOULES-AIMÉ Marc Anesthésie et Réanimation Chirurgicale (48.01)

M. ROBERT Philippe Psychiatrie d'Adultes (49.03)

M. SCHNEIDER Stéphane Nutrition (44.04)

M. THYSS Antoine Cancérologie, Radiothérapie (47.02)

M. TRAN Albert Hépato Gastro-entérologie (52.01).

\section{PROFESSEURS PREMIERE CLASSE}

Mme ASKENAZY-GITTARD Florence Pédopsychiatrie (49.04)

M. BARRANGER Emmanuel Gynécologie Obstétrique (54.03)

M. BÉRARD Étienne Pédiatrie (54.01)

M. BONGAIN André Gynécologie-Obstétrique (54.03)

Mme BREUIL Véronique Rhumatologie (50.01)

M. CASTILLO Laurent O.R.L. (55.01)

M. CHEVALLIER Patrick Radiologie et Imagerie Médicale (43.02)

M. DE PERETTI Fernand Anatomie-Chirurgie Orthopédique (42.01)

M. FERRARI Émile Cardiologie (51.02)

M. FERRERO Jean-Marc Cancérologie ; Radiothérapie (47.02)

M. FONTAINE Denys Neurochirurgie (49.02)

M. GIBELIN Pierre Cardiologie (51.02)

M. HANNOUN-LEVI Jean-Michel Cancérologie ; Radiothérapie (47.02)

M. LEVRAUT Jacques Médecine d'urgence (48.05)

M. LONJON Michel Neurochirurgie (49.02)

M. MOUNIER Nicolas Cancérologie, Radiothérapie (47.02)

M. PADOVANI Bernard Radiologie et Imagerie Médicale (43.02)

M. PASSERON Thierry Dermato-Vénéréologie (50-03)

M. PICHE Thierry Gastro-entérologie (52.01) 
Mme RAYNAUD Dominique Hématologie (47.01)

M. ROSENTHAL Éric Médecine Interne (53.01)

M. STACCINI Pascal Biostatistiques et Informatique Médicale (46.04)

M. THOMAS Pierre Neurologie (49.01)

M. TROJANI Christophe Chirurgie Orthopédique et Traumatologique (50.02)

\section{PROFESSEURS DEUXIEME CLASSE}

Mme ALUNNI Véronique Médecine Légale et Droit de la Santé (46.03)

M. ANTY Rodolphe Gastro-entérologie (52.01)

M. BAHADORAN Philippe Cytologie et Histologie (42.02)

Mme BAILLIF Stéphanie Ophtalmologie (55.02)

Mme BANNWARTH Sylvie Génétique (47.04)

M. BENIZRI Emmanuel Chirurgie Générale (53.02)

M. BENOIT Michel Psychiatrie (49.03)

M. BERTHET Jean-Philippe Chirurgie Thoracique (51-03)

M. BOZEC Alexandre ORL- Cancérologie (47.02)

M. BREAUD Jean Chirurgie Infantile (54-02)

Mme BUREL-VANDENBOS Fanny Anatomie et Cytologie pathologiques (42.03)

M. CHEVALIER Nicolas Endocrinologie, Diabète et Maladies Métaboliques (54.04)

Mme CHINETTI Giulia Biochimie-Biologie Moléculaire (44.01)

M. CLUZEAU Thomas Hématologie (47.01)

M. DELLAMONICA Jean réanimation médicale (48.02)

M. DELOTTE Jérôme Gynécologie-obstétrique (54.03)

M FAVRE Guillaume Néphrologie (44-02)

M. FOURNIER Jean-Paul Thérapeutique (48-04)

Mme GIORDANENGO Valérie Bactériologie-Virologie (45.01)

Mme GIOVANNINI-CHAMI Lisa Pédiatrie (54.01)

M. GUÉRIN Olivier Méd. In ; Gériatrie (53.01)

M. IANNELLI Antonio Chirurgie Digestive (52.02)

M. ILIE Marius Anatomie et Cytologie pathologiques (42.03)

M JEAN BAPTISTE Elixène Chirurgie vasculaire (51.04)

M. ROHRLICH Pierre Pédiatrie (54.01)

M. ROUX Christian rhumatologie (50.01) 
M. RUIMY Raymond Bactériologie-virologie (45.01)

Mme SACCONI Sabrina Neurologie (49.01)

M. SADOUL Jean-Louis Endocrinologie, Diabète et Maladies Métaboliques (54.04)

M. VANBIERVLIET Geoffroy Gastro-entérologie (52.01)

\section{MAITRES DE CONFÉRENCES DES UNIVERSITÉS - PRATICIENS HOSPITALIERS}

M. AMBROSETTI Damien Cytologie et Histologie (42.02)

Mme BERNARD-POMIER Ghislaine Immunologie (47.03)

M. BRONSARD Nicolas Anatomie Chirurgie Orthopédique et Traumatologique (42.01)

M. CAMUZARD Olivier Chirurgie Plastique (50-04)

Mme CONTENTI-LIPRANDI Julie Médecine d'urgence ( 48-04)

M. DOGLIO Alain Bactériologie-Virologie (45.01)

M DOYEN Jérôme Radiothérapie (47.02)

M. FOSSE Thierry Bactériologie-Virologie-Hygiène (45.01)

M. GARRAFFO Rodolphe Pharmacologie Fondamentale (48.03)

Mme HINAULT Charlotte Biochimie et biologie moléculaire (44.01)

M. HUMBERT Olivier Biophysique et Médecine Nucléaire (43.01)

Mme LAMY Brigitte Bactériologie-virologie ( 45.01)

Mme LONG-MIRA Elodie Cytologie et Histologie (42.02)

Mme MAGNIÉ Marie-Noëlle Physiologie (44.02)

M. MASSALOU Damien Chirurgie Viscérale ( 52-02)

Mme MOCERI Pamela Cardiologie (51.02)

M. MONTAUDIE Henri Dermatologie (50.03)

Mme MUSSO-LASSALLE Sandra Anatomie et Cytologie pathologiques (42.03)

M. NAÏMI Mourad Biochimie et Biologie moléculaire (44.01)

Mme POMARES Christelle Parasitologie et mycologie (45.02)

M. SAVOLDELLI Charles Chirurgie maxillo-faciale et stomatologie (55.03)

Mme SEITZ-POLSKI Barbara Immunologie (47.03)

M. SQUARA Fabien Cardiologie (51.02)

M. TESTA Jean Épidémiologie Économie de la Santé et Prévention (46.01)

Mme THUMMLER Susanne Pédopsychiatrie (49.04)

M. TOULON Pierre Hématologie et Transfusion (47.01) 
MAITRE DE CONFÉRENCES DES UNIVERSITÉS

M. DARMON David Médecine Générale (53.03)

Mme GROS Auriane Orthophonie (69)

PROFESSEURS AGRÉGÉS

Mme LANDI Rebecca Anglais

PRATICIEN HOSPITALIER UNIVERSITAIRE

M. DURAND Matthieu Urologie (52.04)

M. SICARD Antoine Néphrologie (52-03)

\section{PROFESSEURS ASSOCIÉS}

M. GARDON Gilles Médecine Générale (53.03)

Mme MONNIER Brigitte Médecine Générale (53.03)

\section{MAITRES DE CONFÉRENCES ASSOCIÉS}

Mme CASTA Céline Médecine Générale (53.03)

M. GASPERINI Fabrice Médecine Générale (53.03)

M. HOGU Nicolas Médecine Générale (53.03)

Professeurs Honoraires

M. AMIEL Jean

M ALBERTINI Marc

M. BALAS Daniel

M. BATT Michel

M. BLAIVE Bruno

M. BOQUET Patrice

M. BOURGEON André
M. GASTAUD Pierre

M. GÉRARD Jean-Pierre

M. GILLET Jean-Yves

M. GRELLIER Patrick

M. GRIMAUD Dominique

M. HOFLIGER Philippe

M. JOURDAN Jacques 


\section{TABLE DES MATIERES}

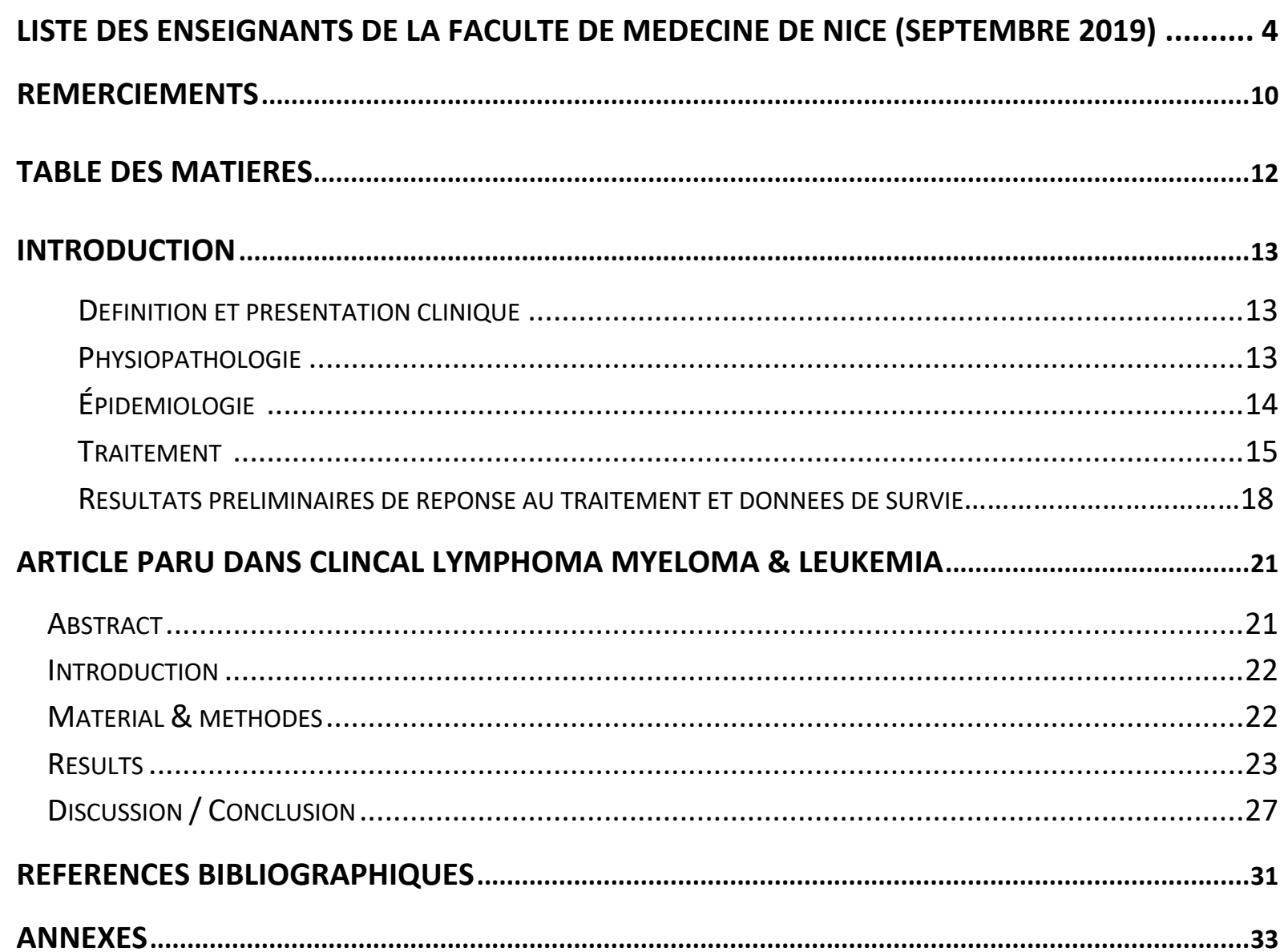

ANNEXE 1 - DEFINITION DES CRITERES DE REPONSE DANS LES LAM SELON ELN 2017 ............................34

ANNEXE 2 - CRITERES DE CLASSIFICATION DES EVENEMENTS INDESIRABLES (CTCAE VERSION 5)................35

ANNEXE 3 - DEFINITION DES CRITERES D'EVALUATION PRONOSTIQUE SELON ELN 2017 .........................36

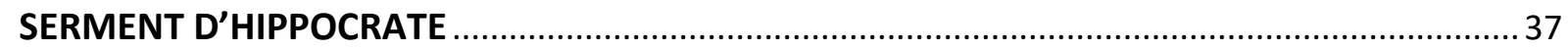




\section{INTRODUCTION}

\section{Définition et présentation clinique}

Les Leucémies Aiguës Myéloïdes (LAM) sont un ensemble d’hémopathies malignes caractérisées, à la fois par un blocage de différenciation de la lignée myéloïde et, par une prolifération incontrôlée des cellules leucémiques. Les blastes s'accumulent dans la moelle osseuse ce qui conduit secondairement à une insuffisance médullaire ${ }^{1}$ et peuvent également infiltrer d'autres organes (atteinte extramédullaire).

La symptomatologie clinique classique résulte de cet envahissement médullaire. L'insuffisance médullaire est composée d'un syndrome anémique (pâleur cutanéo-muqueuse, dyspnée d'effort puis de repos, tachycardie et autres signes d'insuffisance cardiaque en cas de mauvaise tolérance). Un syndrome infectieux causé par la neutropénie peut s'y associer ainsi qu'un syndrome hémorragique². Généralement, les patients vont décrire un syndrome pseudo-grippal, pouvant associer une fièvre, une asthénie et des lipothymies, ainsi que des saignements anormaux et/ou des infections persistantes ${ }^{1}$.

Le syndrome tumoral n'est pas systématiquement retrouvé, comprend rarement des adénopathies ou une localisation neurologique (proche de celle des LAL, surtout en cas de LAM hyperleucocytaire et à composante monocytaire) mais plutôt une splénomégalie (15-20\% des cas), une hyperplasie gingivale et des infiltrations cutanées (leucémides), surtout en cas de LAM à composante monocytaire ${ }^{2}$. Actuellement, les patients sont transférés en service de Médecine Intensive et Réanimation en cas de LAM hyperleucocytaire, de syndrome de lyse nécessitant une épuration extra-rénale, de nécessité d'une oxygénothérapie (liée à une infection ou une leucostase pulmonaire) ou en présence d'une coagulopathie de consommation sévère (CIVD ou fibrinolyse).

\section{Physiopathologie}

La nouvelle classification ELN 2017 retrouvait 23 gènes communément mutés et 237 autres étaient retrouvés mutés de façon non aléatoire dans au moins deux cas. Ces gènes appartiennent à neuf catégories fonctionnelles : facteurs de transcription, gène de la Nucléophosmine 1 (NPM1), gènes suppresseurs de tumeur, gènes régulateurs de la méthylation de l'acide désoxyribonucléique (ADN), gènes du signaling, gènes de modification de la chromatine, facteurs de transcription myéloïdes, gènes du complexe cohésine et gènes du splicéosome. 


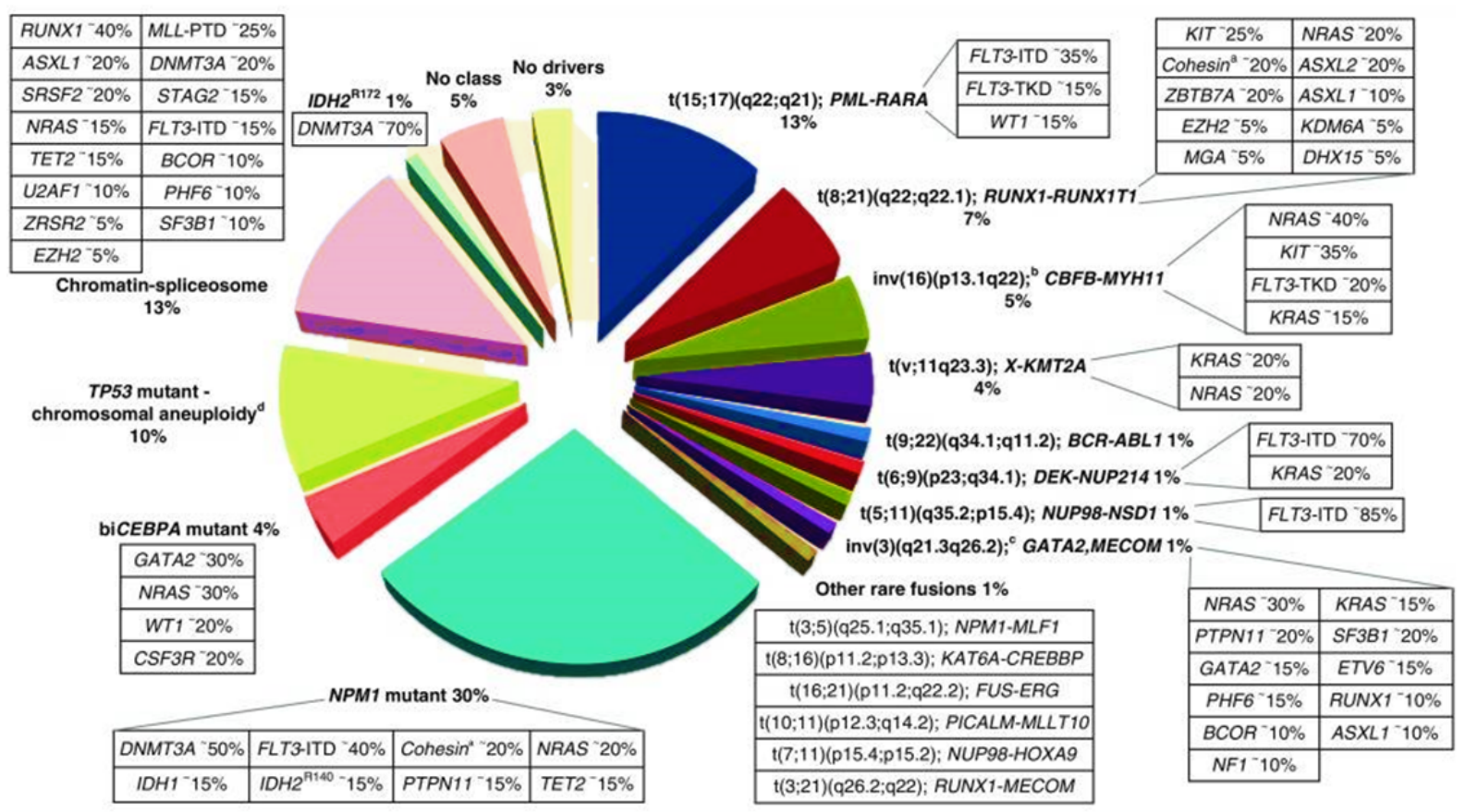

Figure 1. Anomalies du caryotype et mutations retrouvées en biologie moléculaire dans les LAM. D'après ELN 20173.

Les études de l'évolution clonale ont montré que les mutations des gènes impliqués dans la régulation des modifications de l'ADN et de l'état de la chromatine (surtout la DNA-MethylTransferase 3 alpha [DNMT3A], le Ten-eleven-translocation2 [TET2] et le Additional Sex Combs-Like1 [ASXL1]) sont souvent présentes au stade pré-leucémique de la cellule souche ou des progéniteurs et apparaissent précocement dans la leucémogenèse. Ces mutations sont présentes dès les cellules pluripotentes, peuvent persister après traitement et réinduire une expansion clonale et donc une rechute.

Le modèle le plus fréquemment évoqué est un modèle "double hit " (deux coups). Un premier dommage génétique de classe 1 menant à l'activation constitutive de l'hématopoïèse (RAS, Fms-Like Tyrosine Kinase 3 [FLT3], ou encore le Récepteur de Cytokines à activité Tyrosine Kinase [c-KIT]) puis un second de classe 2 menant à l'hyperexpression de gènes HOX ou de gènes de fusion bloquant la différenciation myéloïde. Cependant, ce modèle ne prend pas en compte l'implication de facteurs épigénétiques comme des gènes régulant l'hyperméthylation de gènes suppresseurs de tumeurs ce qui induit leur inactivation. L'implication du stroma médullaire via CXCL12 qui est le ligand du récepteur CXCR4 présent sur les blastes ${ }^{3}$.

\section{Epidémiologie}

Alors que les Leucémies Aiguës Lymphoblastiques (LAL) représentent $90 \%$ des leucémies de l'enfant, chez l'adulte, les LAM sont les leucémies les plus fréquentes. Leur incidence augmente avec l'âge. En Europe, elle est de 5 à 8 cas/100 000 habitants dans la population générale et jusqu'à 25 cas/100 000 
habitants chez les personnes âgées de plus de 65 ans $^{1}$. Les LAM touchent 1.5 fois plus d'hommes que de femmes et l'âge médian de présentation est de 70 ans $^{2}$.

Les LAM sont des pathologies systématiquement mortelles à court terme sans traitement. Chez les patients traités, la mortalité globale des LAM est estimée à 4 à 6 cas/100 000 habitants/an. De grandes disparités existent cependant, selon l'âge du patient, le taux de leucocytes, le type de LAM et les comorbidités ${ }^{1}$. Ainsi, les LAM 3 dans l'ancienne classification FAB (French and British classification) ou leucémie aiguë promyélocytaire sont de très bon pronostic avec une survie globale à 5 ans de plus de $90 \%{ }^{4}$. Au contraire, les patients de plus de 65 ans ou très comorbides (" unfit " à la chimiothérapie intensive) ont un pronostic médiocre avec une survie globale de $10 \%$ à 5 ans $^{5}$. Cependant, cette limite des 65 ans tend aujourd'hui à être repoussée devant l'amélioration des soins de support et le meilleur état général des patients de plus de 65 ans de nos jours ${ }^{3}$.

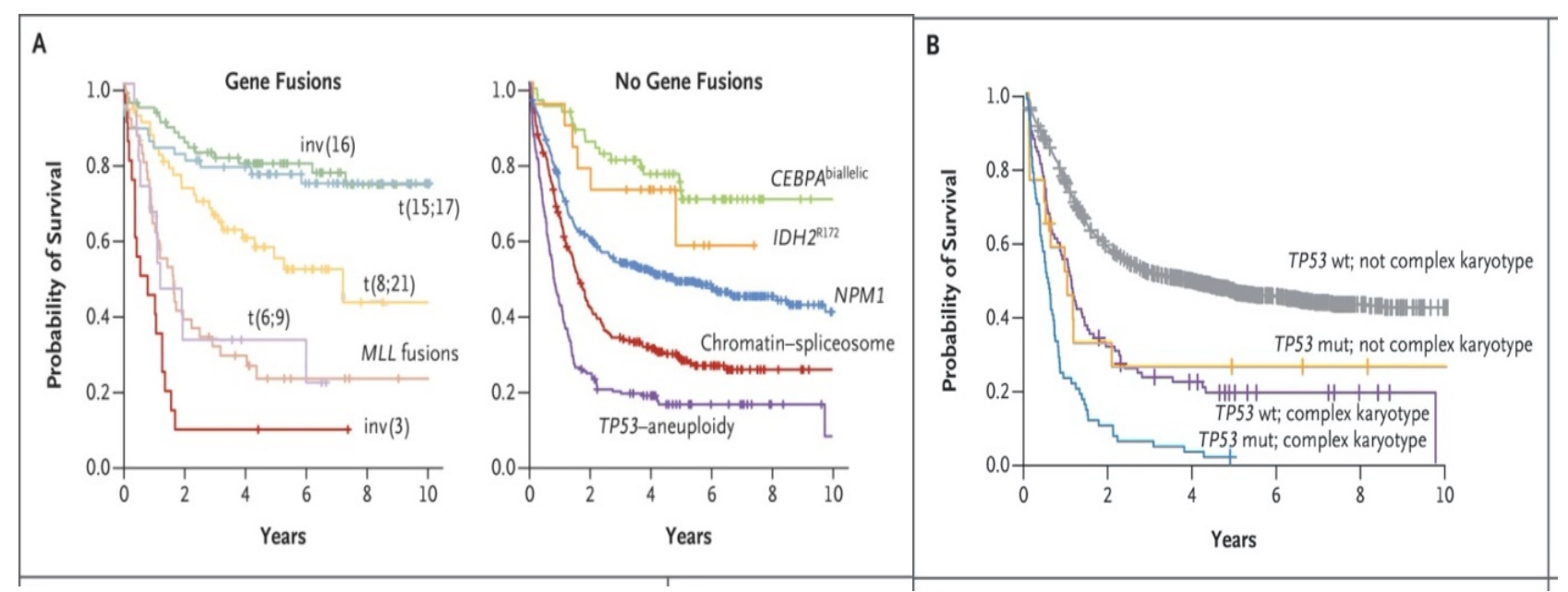

Figure 2. Survie des patients atteints de LAM selon leurs mutations retrouvées en biologie moléculaire et/ou leur caryotype. Adapté de Papaemmanuil et al., NEJM 2016

\section{Traitement}

Les LAM 3 ont un traitement particulier ne comprenant pas de chimiothérapie mais une combinaison de trioxyde d'Arsenic et d'un dérivé de la vitamine $A$, l'acide tout-trans-rétinoïque A (ATRA). Le protocole de référence pour l'induction des patients atteints de LAM (autre que LAM 3) éligibles à la chimiothérapie intensive, est appelé « $3+7$ » et est composé d'injections intraveineuses (IV) d'anthracyclines (Daunorubicine ou Idarubicine) 3 jours de suite, associées à de l'Aracytine en IV continue (IVSE) pendant 7 jours $^{1}$. Chez les patients de moins de 60 ans, on obtient 60 à $80 \%$ de RC et 40 à $60 \%$ chez les plus de 60 ans $^{3}$. Les patients éligibles reçoivent ensuite trois cycles de chimiothérapie de consolidation par fortes doses d'Aracytine 1,5 à $3 \mathrm{~g} / \mathrm{m}^{2} / 12 \mathrm{~h}$ à $\mathrm{J} 1$, J3 et J5 (HDAC) puis une allogreffe 
de cellules souches hématopoïétiques (CSH) (sauf cas particulier, comme les LAM avec caryotype normal et mutation de NPM1 isolée ou associée à FLT3 ITD avec un ratio < 50\%; ou une double mutation de CEBPA ou si présence de transcrit de fusion de type core-binding factors; en RC1 avec une maladie résiduelle (MRD) 2 retrouvant une diminution de plus de 3 log par rapport au diagnostic). Dans les LAM de risque intermédiaire ou haut risque l'allogreffe de CSH en première RC a montré une amélioration de la survie de $20 \%$ à $50 \%{ }^{6}$.

La complication majeure des anthracyclines consiste en une toxicité cardiaque (diminution de la fraction d'éjection du ventricule gauche [FEVG], apparition d'une cardiopathie dilatée, etc.). Dans une grande étude multicentrique visant à évaluer le « $3+7$ » avec de la Daunorubicine à $90 \mathrm{mg} / \mathrm{m}^{2}$ chez les patients âgés sans comorbidité cardiaque connue (critère d'exclusion de l'étude) on retrouvait ainsi $5.9 \%$ de décès en première rémission complète $(\mathrm{RC})$ dus à cette complication. Le " $3+7$ » chez ces patients âgés (médiane d'âge 67 ans) conduisait à $52 \%$ de RC et $31 \%$ de survie globale à 2 ans ${ }^{7}$. Les antécédents de pathologie cardiaque, avec une FEVG $<50 \%$, et l'exposition antérieure aux anthracyclines, estimée par une dose maximale cumulée $>550 \mathrm{mg} / \mathrm{m}^{2}$ de Daunorubicine ou d'équivalent, constituent à présent des contre-indications formelles aux anthracyclines. Cette deuxième contre-indication est fréquemment retrouvée chez les patients atteints de LAM secondaire à une chimiothérapie (antécédent de lymphome ou de cancer solide) ainsi que chez les patients en rechute. II n'existe pas de protocole de traitement consensuel chez ces patients. D'autre part, les patients avec comorbidités cardiaques sont également récusés pour l'allogreffe de CSH car la FEVG < $50 \%$ est retenue comme une contre-indication formelle du fait de l'augmentation de la mortalité liée au traitement (TRM). Pour ces patients, il n'existe pas de protocole de référence définissant un traitement à privilégier, et des différences de prise en charge existent donc entre les centres et même entre les praticiens d'un même centre.

De nombreux traitements sont actuellement en cours d'étude dans les LAM (Figure 3), dont les toxicités sont encore partiellement inconnues mais qui pourraient peut-être être utilisables pour ce type de patients dans le futur ${ }^{3}$.

En attendant ces évaluations et l'établissement d'une balance bénéfice-risque pour ces traitements, nous avons choisi de comparer des protocoles utilisant des molécules connues, dont les effets secondaires sont prévisibles chez ces patients avec un pronostic déjà altéré du fait de la contreindication aux anthracyclines et à l'allogreffe.

La Fludarabine est un analogue des purines de la famille des anti-métabolites, utilisé en oncologie depuis les années 1960. Le protocole IDAFLAG composé d'Idarubicine associée à un FLAG : Fludarabine 
et Cytarabine avait montré $56 \%$ de RC + RCi chez les patients réfractaires ou en rechute de LAM avec une survie globale médiane à 15 mois $^{8}$. Le protocole FLAG seul a lui montré $30 \%$ de RC et une survie globale médiane de. 3,2 mois chez des patients âges réfractaires ou en rechute de LAM $^{9}$. La Clofarabine est assez proche de la Fludarabine vu son statut d'analogue des purines de seconde génération. En monothérapie, dans les LAM unfit, elle a montré $40 \%$ de $\mathrm{RC}^{10}$ et chez des patients âgés, associée à de faibles doses de Cytarabine (protocole CLARA) elle a montré. $60 \%$ de RC et $30 \%$ de survie globale à 2 ans $^{11}$. Enfin, le Topotecan est un inhibiteur de la Topoisomérase I, initialement développé pour les cancers solides (ovaire, ORL, poumon). Son association avec la Cytarabine a montré $81 \%$ de RC et une survie globale à 2 ans de $66 \%{ }^{12}$.

Les études ne retrouvent pas de toxicité majeure associée à ces protocoles. Ainsi notre étude a voulu comparer trois protocoles sans anthracycline, FLAG, CLARA et TA, chez les patients atteints de LAM et avec des contre-indications aux anthracyclines.

Modulateurs épigénétiques :

- Inhibiteurs de DNA methyltransférase (SGI-110)

- Inhibiteurs de HDAC

- Inhibiteurs d'IDH1 et IDH2

- Inhibiteurs de DOT1L

- Inhibiteurs de BET-bromodomaines
Anticorps et immunothérapies :

- Anticorps monoclonaux anti-CD33, CD44, CD47, CD123, CLEC12A

Immunoconjugués (Gemtuzumab Ozogamicin, SGN-33A)

- "Bispecific T-cell engager » (BiTEs) et " dual-affinity retargeting molecule » (DARTs)

- Cellules T avec récepteur chimérique à l'antigène (CAR T cells)

Inhibiteurs du checkpoint (PD-1/PDL-1, CTLA-4)

Anticorps anti-KIR

- Vaccins (WT1)

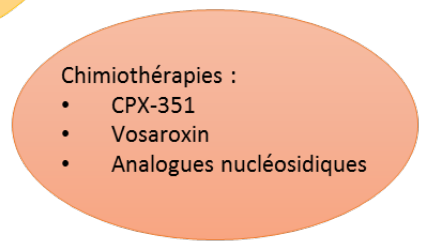

Nouveaux traitements des LAM

Inhibiteurs mitochondriaux:

- Inhibiteurs de Bcl-2, Bcl-xL, Mcl-1

- Inhibiteurs de protéases caséinolytiques

Figure 3. Nouvelles thérapies dans la prise en charge des LAM.

\section{Résultats préliminaires de réponse au traitement et données de survie}

Comme expliqué ci-dessous, nous avons choisi de ne publier que les résultats de survie concernant l'étude en sous-groupe. Les résultats de la cohorte globale sont donc présentés ici. 
Une rémission complète a été atteinte chez $56 \%$ des patients après induction, $71,4 \%(n=20 / 28)$ dans le groupe FLAG/CLARA et $62,5 \%(n=15 / 24)$ dans le groupe TA. Après avoir atteint une RC, seulement six patients ont bénéficié d'un traitement de consolidation, trois dans chaque groupe (15\% vs $20 \%$ pour FLAG/CLARA et TA respectivement). Les protocoles étaient, dans le groupe FLAG/CLARA, de I'Azacitidine pour 2 patients et un protocole CLARA pour le troisième, et, dans le groupe TA, deux protocoles TA et un protocole d'IDAC. Dix-huit patients dans notre étude ont pu bénéficier d'une ASCT, douze dans le groupe FLAG/CLARA et six dans le groupe TA. Compte tenu de cette différence, nous avions choisi de censurer les résultats présentés à la date de l'allogreffe pour n'étudier que les effets des chimiothérapies.

Dans l'étude du pronostic de ces patients, nous avons montré que la survie globale médiane n'était pas différente entre les deux groupes $(9,8$ mois $[1,1-22,1]$ vs 10,2 mois $[1,1-19,2]$ pour les groupes FLAG/CLARA et TA, respectivement, $p=0,59$ ) (Figure 4). $D$ 'autre part, on retrouvait une tendance vers

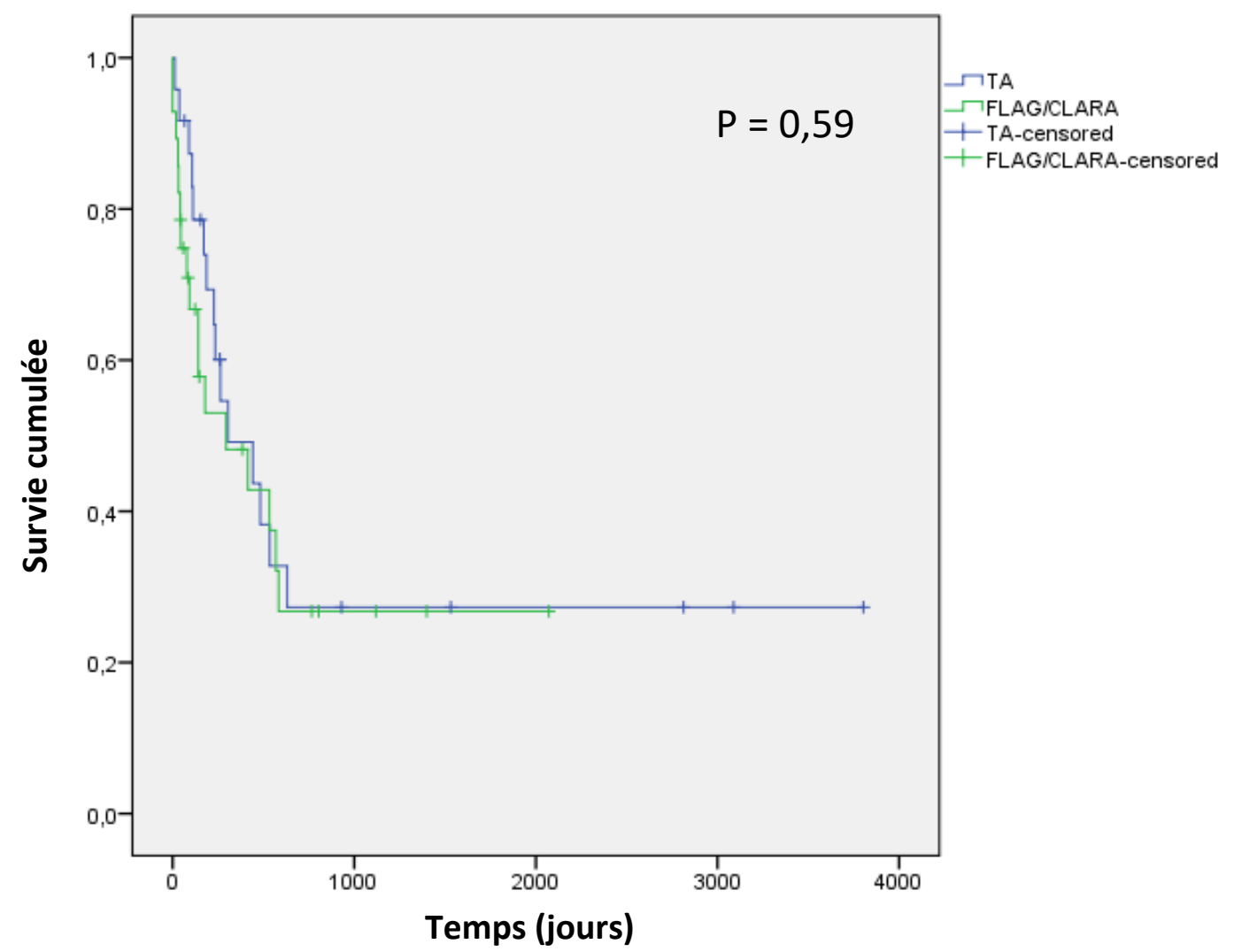

Figure 4. Survie cumulée globale de la cohorte exprimée en jours. Les croix représentent les patients censurés.

une meilleure médiane de survie sans rechute dans le groupe TA $(1,6$ mois $[3,6-9,2]$ vs 8,8 mois $[5,6$ 11,9], pour les groupes FLAG/CLARA et TA, respectivement, $p=0,09)$. Lorsqu'on censurait les données à la date de l'ASCT, comme expliqué précédemment, ces résultats devenaient significatifs avec 4,7 mois $[4,3-5,1]$ vs $16,1[8,4-23,7]$, pour les groupes FLAG/CLARA et TA, respectivement, $p=0,001$ ) (Figure $5)$. 


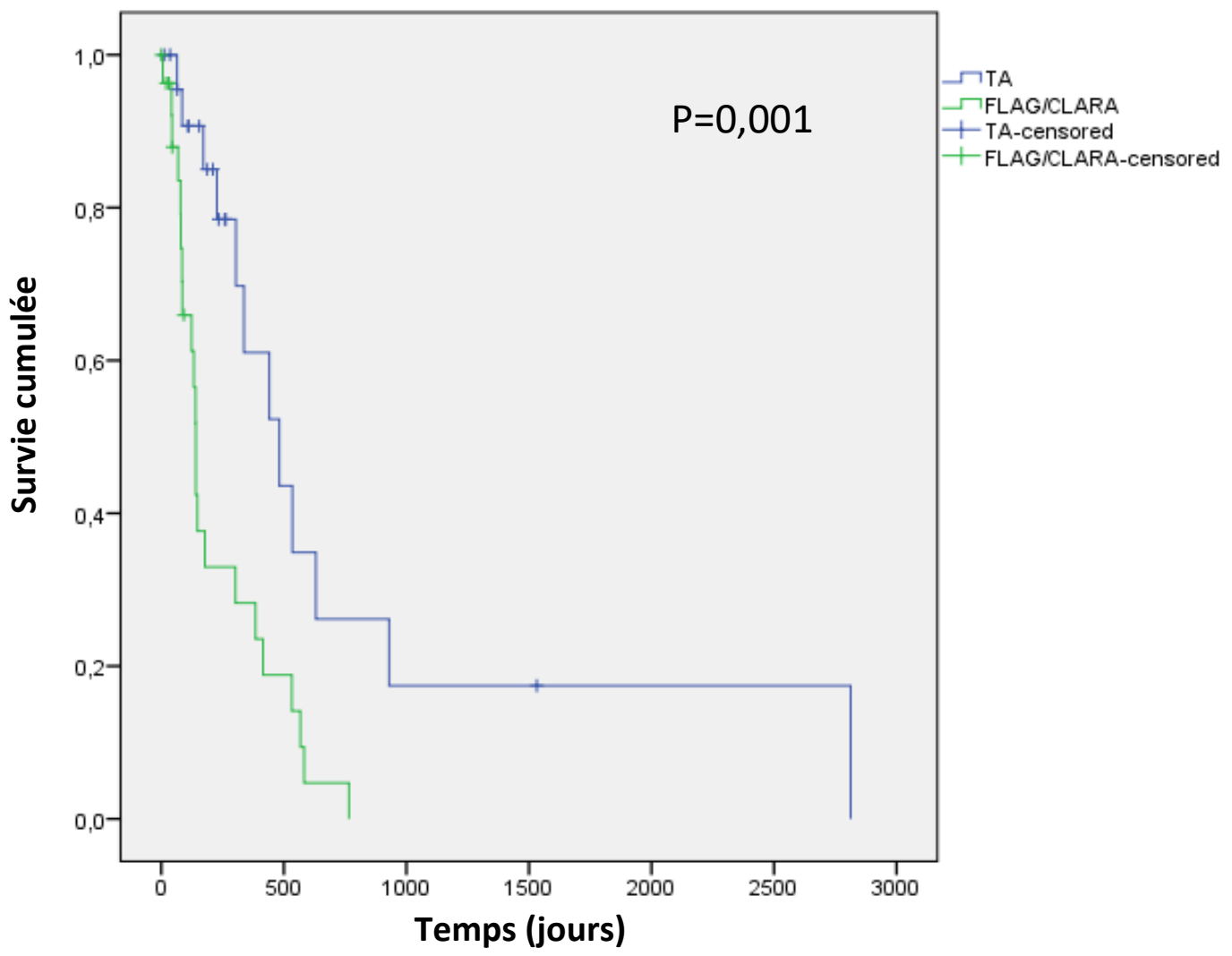

Figure 6. Survie cumulee sans rechute censurèe à l'allogreffe pour TA vS FLAG/CLARA.

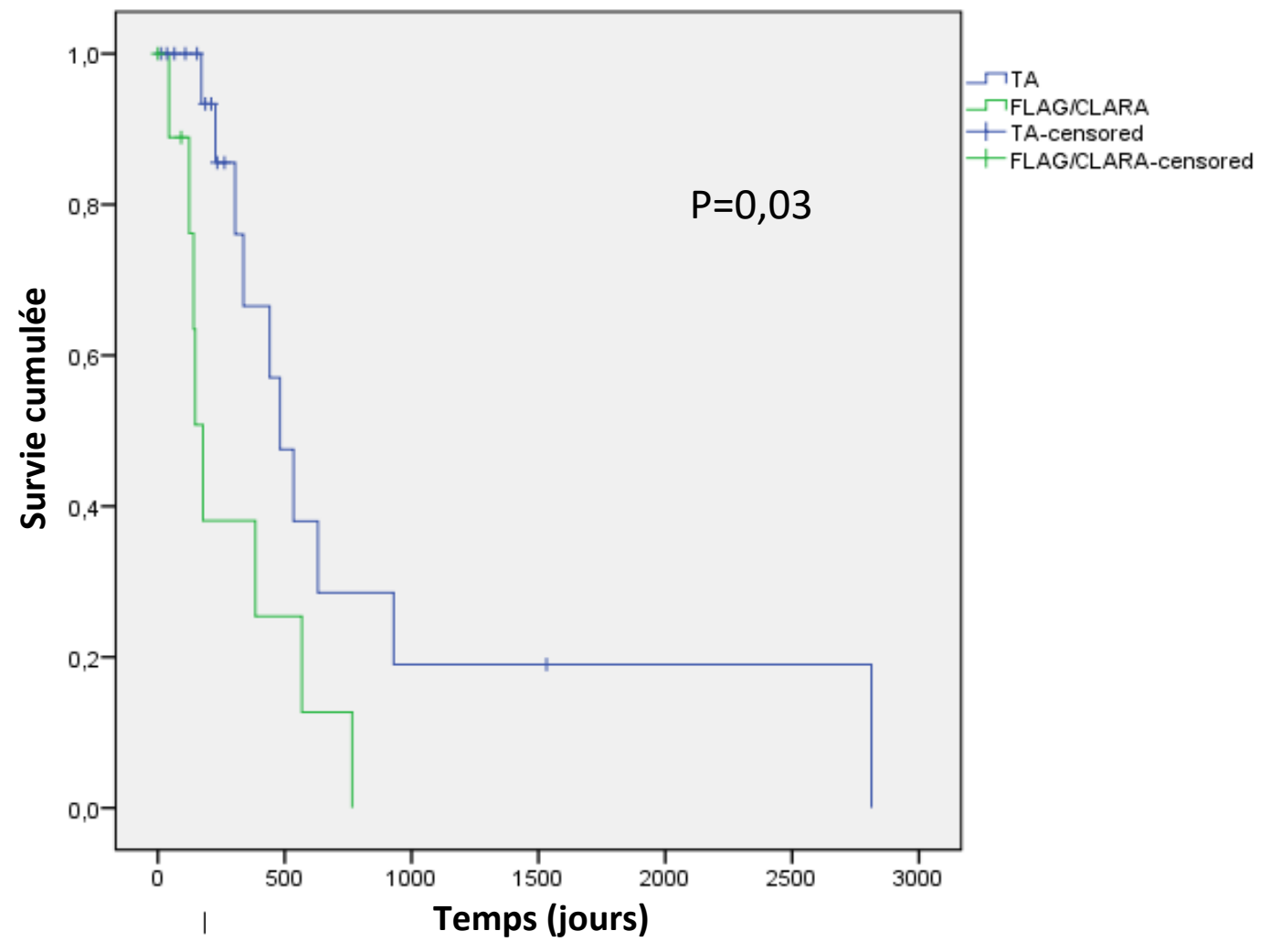

Figure 5. Survie cumulée sans rechute censurée à l'allogreffe dans le sous-groupe des LAM nouvellement diagnostiquées (en jours).

En analyse multivariée, cet effet était également retrouvé dans le sous-groupe des patients nouvellement diagnostiqués $(5,9$ mois $[4,3-7,6]$ vs 16,1 mois $[11,2-20,9]$, pour les groupes FLAG/CLARA 
et $T A$, respectivement, $p=0,03$ ) (Figure 6) et encore plus marqué dans le sous-groupe de pronostique défavorable selon la classification ELN $(4,1$ mois $[2,1-6,1]$ vs 17,8 mois $[1,1-32,5]$, pour les groupes FLAG/CLARA et TA, respectivement, $p=0,006$ ) (Figure 7).

La médiane de temps avant la rechute était également plus courte dans le groupe FLAG/CLARA par rapport au groupe TA ( 4,5 mois vs 16 mois).

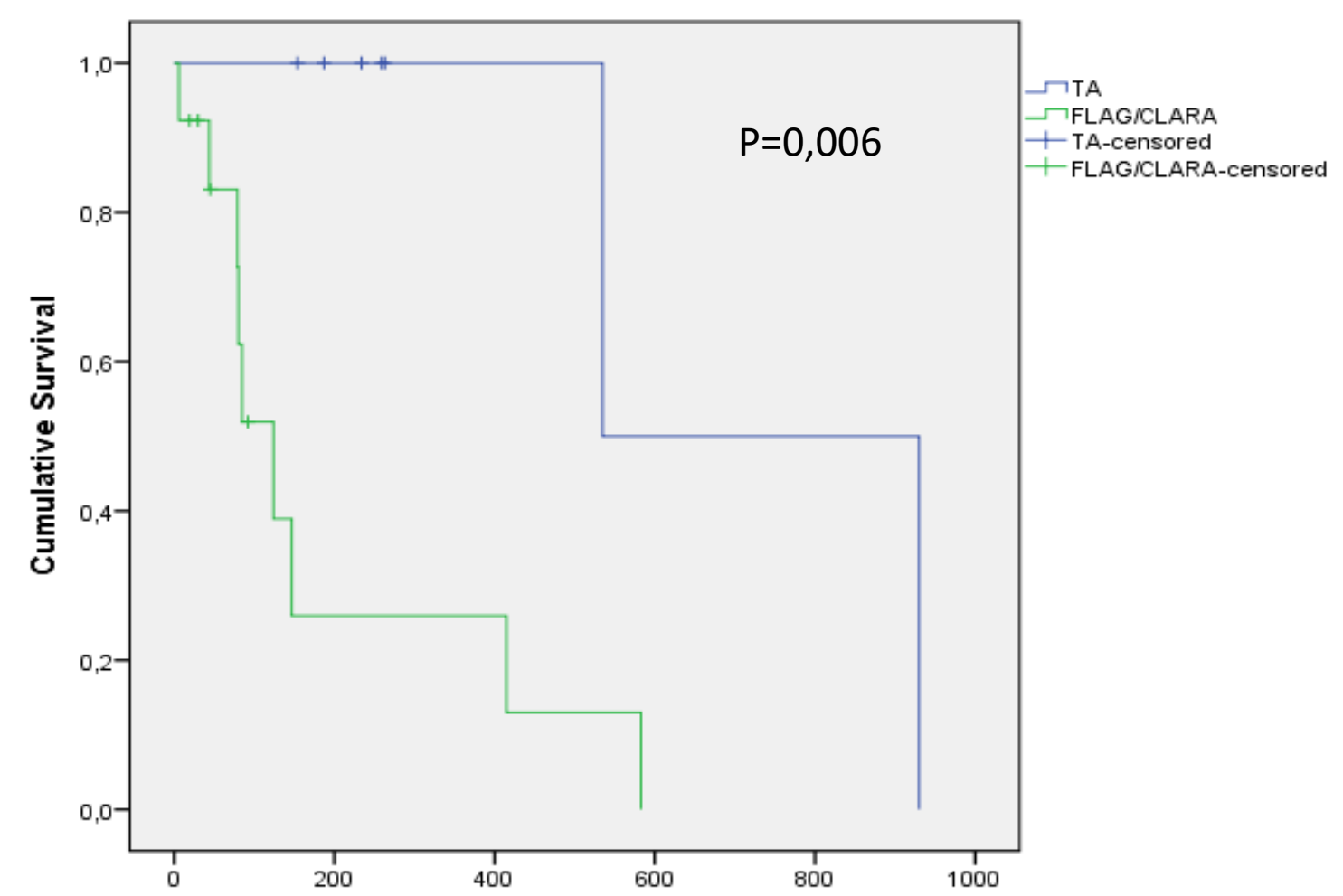

Figure 7. Survie cumulée sans rechute censurée à l'allogreffe dans le sous-groupe des LAM de pronostique défavorable selon l'ELN (en jours).

Cependant, les patients dans le groupe FLAG/CLARA sont apparus comme appartenant à un groupe de risque plus défavorable que ceux du groupe TA du point de vue cytogénétique (groupe favorable : 3,6\% vs $12,5 \%$; groupe défavorable: $46,4 \%$ vs $29,2 \%$ pour le groupe FLAG/CLARA et le groupe TA respectivement), de l'existence de mutations NPM1 (0\% dans le groupe FLAG/CLARA vs $16.7 \%$ dans le groupe TA) ou du statut de la maladie (maladie en rechute ou réfractaire dans $64,3 \%$ des patients du groupe FLAG/CLARA vs $16,7 \%$ des patients du groupe TA, $p=0,002$ pour le statut de la maladie).

Nous avons donc décidé d'étudier les patients selon le statut de leur maladie, nouvellement diagnostiqué ou en rechute/réfractaire, afin de limiter les facteurs confondants. 


\title{
Alternative Effective and Safe Induction Regimens for Newly Diagnosed Acute Myeloid Leukemia in Patients With Cardiac Contraindication to Anthracyclines
}

\author{
Clemence Marcault, ${ }^{1,2}$ Geoffroy Venton, ${ }^{3}$ Lauris Gastaud, ${ }^{4}$ Lionel Mannone, ${ }^{1}$ \\ Jerome Rey, ${ }^{3}$ Evelyne D'Incan, ${ }^{3}$ Colombe Saillard, ${ }^{3}$ Aude Charbonnier, ${ }^{3}$ \\ Sophie Raynaud, ${ }^{2}$ Norbert Vey, ${ }^{5}$ Thomas Cluzeau ${ }^{1,6}$
}

\begin{abstract}
There is no commonly agreed-on therapeutic regimen for acute myeloid leukemia patients with a contraindication to receiving anthracyclines (eg, because of cardiac dysfunction or prior exposure to anthracyclines). Our study compared 3 anthracycline-free regimens currently used in France. Despite the poor outcome of these patients, topotecan plus cytarabine is effective and safe in these patients.

Introduction: The standard first-line treatment for acute myeloid leukemia (AML) is a combination of cytarabine and anthracyclines. To date, there is no commonly agreed-on regimen for patients who are ineligible for this therapy because of cardiac comorbidities or prior exposure to anthracyclines. We compared 3 anthracycline-free regimens currently used in France. Patients and Methods: Two patients with newly diagnosed or relapsed/refractory AML were treated intensively in 3 French centers. All patients had at least one contraindication to the receipt of anthracyclines. Three regimen types were used: fludarabine, cytarabine, and granulocyte-colony stimulating factor (FLAG); clofarabine and cytarabine (CLARA); and topotecan plus cytarabine (TA). Results: Thirty patients (58\%) had de novo AML. The European LeukemiaNet 2013 risk categories were favorable, intermediate, and adverse in 4 (8\%), 27 (52\%), and 20 (39\%) patients, respectively. Twenty-four patients received TA and 28 FLAG/CLARA regimens. Fifty percent of patients had cardiac dysfunction, and $50 \%$ had prior anthracycline exposure above the maximum tolerated dose. The rate of cardiac events was similar after TA $(17 \%)$ and FLAG/CLARA $(25 \%)(P=.78)$. The 5-year nonrelapse mortality was $17.9 \%$ and $12.5 \%$ in the TA and FLAG/CLARA groups, respectively $(P=.59)$. In patients with previously untreated AML, complete response occurred in $18(72 \%)$ of 25 , but median overall survival was only 9.7 months. Conclusion: TA, FLAG, and CLARA regimens are efficient and are associated with acceptable toxicity in AML patients ineligible for the $3+7$ regimen as a result of cardiac comorbidities. However, long-term outcome remains disappointing, thereby highlighting the need for the development of less toxic regimens.
\end{abstract}

Clinical Lymphoma, Myeloma \& Leukemia, Vol. m, No. a, m-n (c) 2019 Elsevier Inc. All rights reserved.

Keywords: Adverse, AML, Clofarabine, Comorbidities, Topotecan

N.V. and T.C. contributed equally to this article.

${ }^{1} \mathrm{CHU}$ of Nice, Hematology Department ${ }^{2} \mathrm{CHU}$ of Nice, Oncohematology Laboratory, Cote D'Azur University, Nice Sophia
Antipolis University, Nice, France

${ }^{3}$ Hemarology Department, Paoli-Calmettes Institute, Marseille, France

${ }^{4}$ Oncology Department, Antoine Lacassagne Center, Nice, France

${ }^{5}$ Department of Clinical Hematology, Paoli-Calmettes Institute, Masseille, France

'Department of Clinical Hematology, Paoli-Calmettes Institute, Marseille, France
'INSERM U1065, Mediterranean Center of Molecular Medecine, Cote D'Azur

University, Nice, France

Submitted: Jul 16, 2019; Revised: Nov 4, 2019; Acceptod: Nov 19, 2019

Address for correspondence Thomas Cluzeau, MD, PhD, CHU of Nice, Hematology Deparment, 151 oute Saint Antoine de Ginestière, 06200 Nice, France E-mail contac: cluzeau.telechu-nice.fi 
ARTICLE IN PRESS

\section{Cardiac Contraindication to Anthracyclines}

\section{Introduction}

The mainstay of treatment for acute myeloid leukemia (AML) patients eligible to receive intensive chemotherapy is the $3+7$ regimen: daunorubicin provided intravenously for 3 days, then cytarabine provided intravenously continuously for 7 days. Cardiac toxicity is a major complication of anthracycline-containing regimen and accounted for $5.9 \%$ of the death in first complete response (CR) in a large multicenter study evaluating the $3+7$ regimen with daunorubicin at a dose of $90 \mathrm{mg} / \mathrm{m}^{2}$ in elderly patients without cardiac comorbidity as per protocol eligibility criteria. ${ }^{1}$ Cardiac dysfunction or prior exposure to cumulative dose of $>550 \mathrm{mg} / \mathrm{m}^{2}$ of daunorubicin or its equivalents are classical contraindications to the use of anthracyclines. Prior exposure is frequently observed in patients who develop therapy-related AMLs (eg, after lymphomas or solid tumor) and in patients with relapsed AML, who often received anthracyclines during their first line therapy. Several anthracyclinefree induction regimens have been developed and may be used in these patients, but as a result of lack of data, no standard therapy has yet been established.

Fludarabine and clofarabine are antimetabolites that have been used in combination with cytarabine and may represent potential alternatives. In de novo AML, the IDAFLAG regimen (combining idarubicin, fludarabine, cytarabine, and granulocyte-colony stimulating factor) showed a CR rate of $82 \%$, with a 5 -year overall survival (OS) of $43 \% .^{2}$ Clofarabine, a second-generation nucleoside analog, was active as single agent in unfit patients, with a $\mathrm{CR}$ rate of $40 \%,{ }^{3,4}$ and in older patients in association with low-dose cytarabine, with a CR rate at $60 \%$ and a 2 -year OS rate of about $30 \%{ }^{5}$ Topotecan is a topoisomerase I inhibitor initially developed for solid tumors (ovarian, cervical, lung). In combination with cytarabine ${ }^{6}$ for the treatment of AML, topotecan is associated with a CR rate of $81 \%$ and a 2 -year OS of $66 \%$, with no unexpected toxicity? $^{\text {? }}$

In this study, we aimed to retrospectively compare these 3 regimens in AML patients with contraindications to anthracyclines.

\section{Patients and Methods \\ Patients}

Fifty-two AML patients treated between 2008 and 2016 in 3 French centers (CHU of Nice, Antoine Lacassagne Center in Nice, and Institut Paoli-Calmettes in Marseille) were retrospectively included in this study. Inclusion criteria were as follows: age $>18$ years, newly diagnosed or relapsed/refractory (R/R) AML (defined by at least $20 \%$ of blasts in the bone marrow), and either cardiac dysfunction (left ventricular ejection fraction $<50 \%$ ) or history of neoplasm and maximal anthracyclines cumulative dose already reached $\left(550 \mathrm{mg} / \mathrm{m}^{2}\right)$. These comorbidities were contraindications to anthracyclines. Acute promyelocytic leukemia was excluded. Clinical, cytogenetic (Q-banded chromosome study and fluorescence in-situ hybridization conducted at diagnosis, 30 days after induction, and during follow-up), and response data were collected for all patients, and molecular data (FLT3 internal tandem duplication [ITD], NPM1 gene mutation A, CEBP $\alpha$ double mutation) were collected when available. The risk groups were established according to European LeukemiaNet (ELN) 2017 criteria. $^{8}$

\section{Treatment Regimens}

Three types of anthracycline-free regimens were used for induction at the different institutions participating in the study. The FLAG regimen combined fludarabine (days $1-4,30 \mathrm{mg} / \mathrm{m}^{2}$ per day), cytarabine (days $1-4,2000 \mathrm{mg} / \mathrm{m}^{2}$ per day), and granulocytecolony stimulating factor (day 0 up to absolute neutrophil count $>1 \times 10^{9} / \mathrm{L}, 400 \mu \mathrm{g} / \mathrm{m}^{2}$ per day). The CLARA regimen combined clofarabine (days 1-3 [or 5], $30 \mathrm{mg} / \mathrm{m}^{2}$ per day) and cytarabine (days 1-7 [or 10], $20 \mathrm{mg} / \mathrm{m}^{2}$ per day). The topotecan plus cytarabine (TA) regimen combined topotecan (days $14,1.25 \mathrm{mg} / \mathrm{m}^{2}$ per day) and cytarabine (days $1-4,1000 \mathrm{mg} / \mathrm{m}^{2}$ per 12 hours on days 1-4). The first two regimens used purine analog and were combined for analysis.

\section{Outcome Definitions}

Complete remission was defined as complete blood count recovery with bone marrow blasts $<5 \%$ upon morphologic assessment. Hematologic relapse was defined as disease recurrence with at least $5 \%$ marrow blasts or recurrence of extramedullary, biopsyproven AML localization. ${ }^{8}$

\section{Statistical Analysis}

Continuous variables are described using median (interquartile range) (minimum; maximum) and qualitative variables using count and percentage. Noncontinuous variables were compared by the chi-square test. Mann-Whitney test was used for continuous variables. Adverse events (AEs) were evaluated according to Common Terminology Criteria for Adverse Events classification. AE were retrospectively collected and could be nonexhaustive. Nonrelapse mortality was defined as the mortality caused by a reason other than AML relapse. OS was calculated from the date of diagnosis to death or last follow-up. Event-free survival (EFS) was measured from the date of CR determination to hematologic relapse, or death from any cause or last follow-up; patients not known to have any of these events were censored on the date they were last examined. OS and EFS were assessed by the Kaplan-Meier method. Statistical analyses were performed by SPSS 22 (IBM, Armonk, NY).

\section{Results \\ Patient Characteristics}

The data of 52 AML patients were studied (Table 1). Median age was 68 years (range, 20-79 years). Twenty-four and 28 patients were treated with TA or FLAG/CLARA regimens, respectively. Thirty patients $(58 \%)$ had previously untreated AML and 22 patients (42\%) R/R AML, including 22 patients already treated with the $3+7$ regimen. According to the World Health Organization 2016 classification, 16 patients $(31 \%)$ had therapy-related myeloid neoplasms, including 13 patients receiving prior anthracycline at limiting doses. ELN 2013 risk categories were favorable in 4 patients (8\%), intermediate in $27(52 \%)$, and adverse in 20 patients (39\%). Only 28 patients were screened for gene mutations. Seven patients had FLT3-ITD (25\%). Four patients had the NPMI mutation (14\%). Reasons for use of the TA or FLAG/CLARA regimens were cardiac dysfunction in 50\% and prior anthracycline exposure above maximal tolerated dose in $50 \%$ of patients. Overall, patients in the FLAG/CLARA group had poorer risk disease in 
Clemence Marcault et al

\begin{tabular}{|c|c|c|c|c|}
\hline Characteristic & FLAG/CLARA $(\mathrm{N}=28)$ & $\mathrm{TA}(\mathrm{N}=24)$ & All $(\mathrm{N}=52)$ & $\boldsymbol{P}$ \\
\hline \multicolumn{5}{|l|}{ Age $M$} \\
\hline Median & 69 & 66 & 68 & .61 \\
\hline Range & $20-79$ & $28-74$ & $20-79$ & \\
\hline Sex Ratio & & & & .39 \\
\hline Female & $15(53.6 \%)$ & $10(41.7 \%)$ & $25(48.1 \%)$ & \\
\hline Performance Status & & & & .25 \\
\hline$<2$ & $22(78.6 \%)$ & $19(79.2 \%)$ & $41(78.8 \%)$ & \\
\hline$\geq 2$ & $6(21.4 \%)$ & $5(20.8 \%)$ & $11(21.2 \%)$ & \\
\hline Status of Disease & & & & .002 \\
\hline Newly diagnosed & $10(35.7 \%)$ & $20(83.3 \%)$ & $30(57.7 \%)$ & \\
\hline Relapsed/refractory & $18(64.3 \%)$ & $4(16.7 \%)$ & $22(42.3 \%)$ & \\
\hline ELN Risk Category & & & & .31 \\
\hline Favorable & $1(3.6 \%)$ & $3(12.5 \%)$ & $4(7.7 \%)$ & \\
\hline Intermediate & $14(50 \%)$ & $13(54.2 \%)$ & 27 (51.9\%) & \\
\hline Adverse & $13(46.4 \%)$ & $7(29.2 \%)$ & $20(38.5 \%)$ & \\
\hline \multicolumn{5}{|l|}{ Biological Features } \\
\hline NPM1 mutated & 0 & $4 / 12(33 \%)$ & $4 / 28(1.4 \%)$ & .001 \\
\hline FLT3-ITD & $4 / 16(25 \%)$ & $3 / 12(25 \%)$ & $7 / 28(25 \%)$ & .99 \\
\hline Main Comorbidities & & & & .58 \\
\hline Cardiac & $15(53.6 \%)$ & $11(45.8 \%)$ & $26(50 \%)$ & \\
\hline Anthracycline dose & $13(46.4 \%)$ & $13(54.2 \%)$ & $26(50 \%)$ & \\
\hline
\end{tabular}

Abbreviations: ELN = European LeukemiaNet; FAG/CLARA = fludarabine, cytarabine, and granulocyte-colony stimulating factor/clofarabine and cytarabine; TA = topotecan plus cytarabine

terms of cytogenetic risk (favorable category: $3.6 \%$ vs. $12.5 \%$; adverse category: $46.4 \%$ vs. $29.2 \%$ in the TA group), NPM1 mutations ( $0 \%$ vs. $16.7 \%$ in the TA groups), or disease status (R/R AML: $64.3 \%$ vs. $16.7 \%$ in the TA group). Median time to relapse was shorter in patients treated with CLARA ( 4.5 vs. 16 months in the TA group, respectively).

\section{Toxicity and Hematologic Recovery}

Cardiovascular events occurred in 11 patients (21.2\%), 7 (25\%) of 28 after FLAG/CLARA and 4 (17\%) of 24 after TA (Table 2).
They consisted in congestive heart failure (4 [14.3\%] in the FLAG/CLARA group), acute lung edema (1 [4.2\%] in TA group), atrial fibrillation (1 [3.6\%] in FLAG/CLARA), chest pain (1 [3.6\%] in FLAG/CLARA), and decrease of left ventricular ejection fraction (3 [10.7\%] in FLAG/CLARA and $2[8.3 \%]$ in TA group); the most severe events were 2 cardiac arrests (one in each group, $3.6 \%$ in FLAG/CLARA and $4.2 \%$ in TA group).

Infectious complications occurred in all patients. Documented infections were observed in $53.6 \%$ and $33.3 \%$ of cases in the FLAG/CLARA and TA groups, respectively. There was no

\section{Table 2 Adverse Events}

\begin{tabular}{|c|c|c|c|}
\hline Event & FLAG/CLARA $(\mathrm{N}=28)$ & TA $(N=24)$ & $\boldsymbol{P}$ \\
\hline Cardiovascular events & $7(25 \%)$ & $4(16.7 \%)$ & .31 \\
\hline Cardiac arrest & $1(3.6 \%)$ & $1(4.2 \%)$ & \\
\hline LVEF decrease $\geq 10 \%$ & $3(10.7 \%)$ & $2(8.3 \%)$ & \\
\hline Febrile neutropenia & $28(100 \%)$ & $24(100 \%)$ & NS \\
\hline Material & $15(53.6 \%)$ & $8(33.3 \%)$ & \\
\hline Median duration (days) of severe neutropenia in CR patients (ANC $<500 \mathrm{G} /$ ) & $38(n=12)$ & $23(n=7)$ & .62 \\
\hline Median Duration (Days) of Thrombocytopenia in Patients With CR & $(\mathrm{N}=12)$ & $(\mathrm{N}=7)$ & .03 \\
\hline Moderate $(<50 \mathrm{G} / \mathrm{L})$ & 36.1 & 24.1 & \\
\hline Severe $(<20 \mathrm{G} / \mathrm{L})$ & 23.1 & 22.4 & \\
\hline NRM & $5(17.9 \%)$ & $3(12.5 \%)$ & .59 \\
\hline No. of adverse events & $14(50 \%)$ & $4(18 \%)$ & .001 \\
\hline
\end{tabular}

Abbreviations: ANC = absolute neutrophil count; $\mathrm{CR}=$ complete response; FLAG/CLARA = fludarabine, cytarabine, and granulocyte-colory stimulating factor/dofarabine and cytarabine; $\mathrm{LVEF}=$ left ventricle ejection fraction; NRM $=$ nonrelapse mortality, NS = not significant; TA = topotecan plus cytarabine. 


\section{ARTICLE IN PRESS}

\section{Cardiac Contraindication to Anthracyclines}

Figure 1 OS in Patients With Newly Diagnosed AML

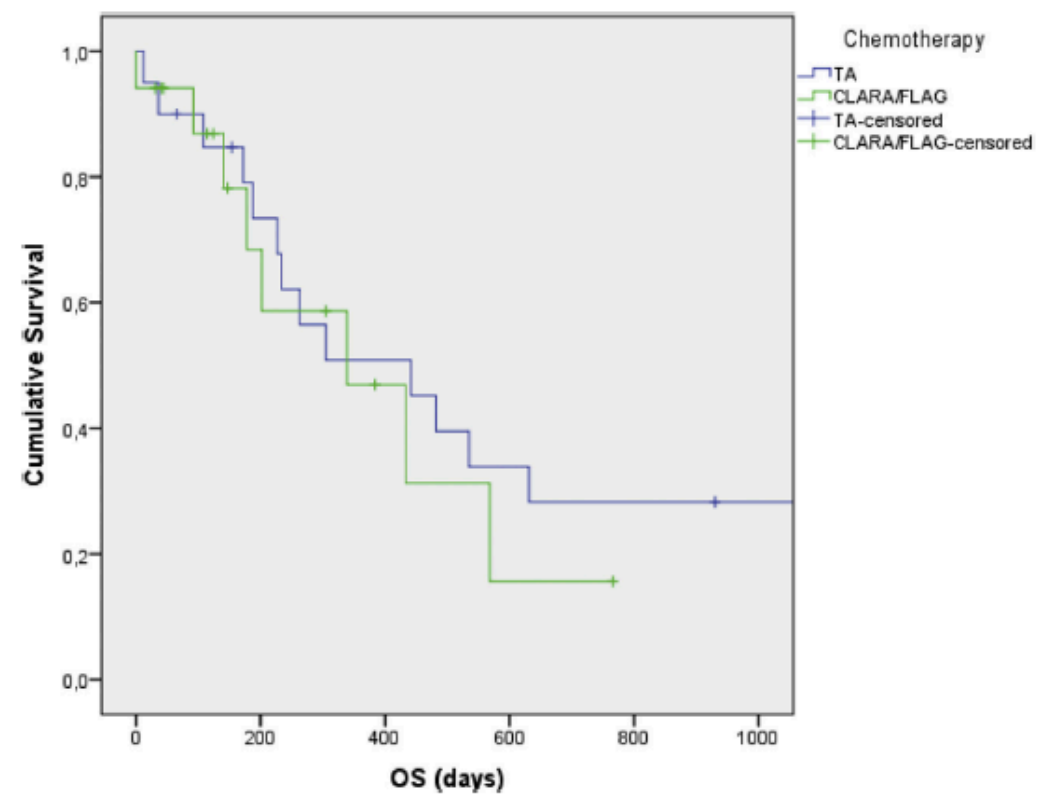

Abbreviations: $\mathrm{AML}=$ acute myeloid leukemia; $\mathrm{OS}=$ overall survival.

Figure 2 EFS in Patients With Newly Diagnosed AML

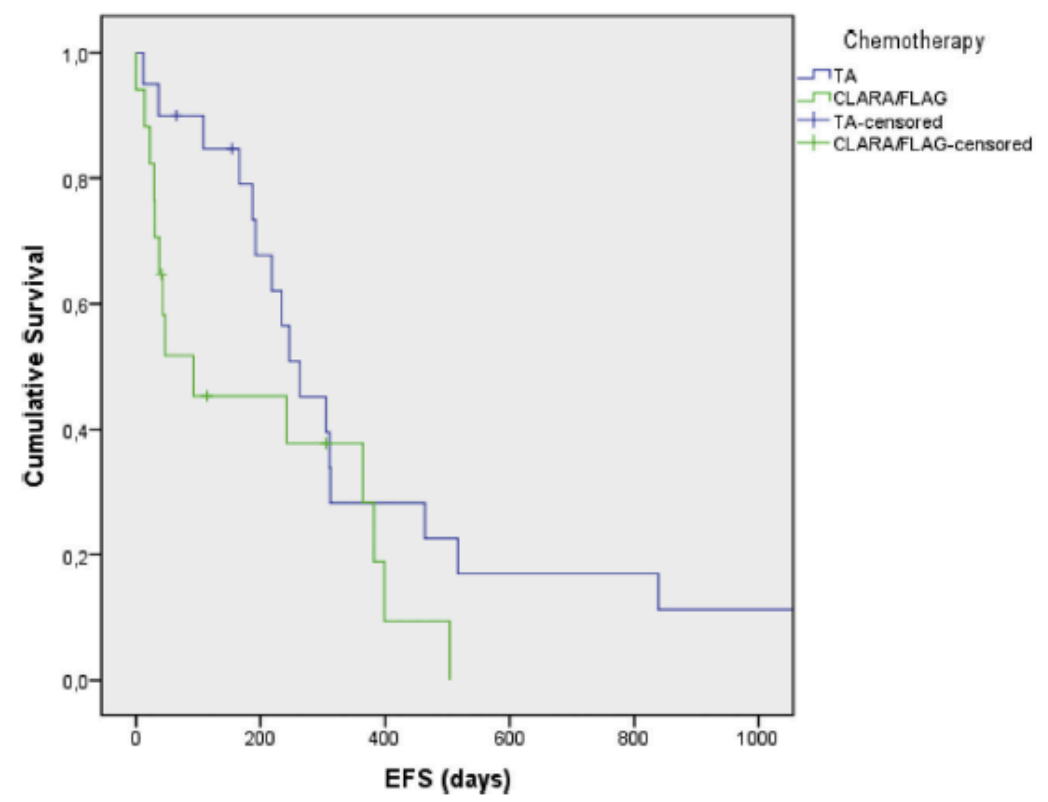

Abbreviations: $\mathrm{AML}=$ acute myeloid leukemia; $\mathrm{ES}=$ event-free survival

4 Clinical Lymphoma, Myeloma \& Leukemia Month 2019 


\section{Clemence Marcault et al}

difference in duration of severe neutropenia in CR between the two groups ( 23 vs. 38 days in the TA and FLAG/CLARA subgroups, respectively, $P=.62$ ). Duration of thrombocytopenia was significantly longer in the FLAG/CLARA group ( 24 vs. 36 days in TA and FLAG/CLARA subgroups, respectively, $P=.03$ ). There were significantly more AEs in the FLAG/CLARA group than in the TA group, with 14 patients $(50 \%)$ versus $4(18 \%)(P=.001)$, and there was no significant difference for early mortality after induction ( 8 weeks), $8 \%$ versus $11 \%$, and for 1 -year mortality, $58 \%$ versus $61 \%$, in the TA and CLARA/FLAG groups, respectively.

\section{Response and Survival}

Median follow-up was 22.5 months. A total of $57 \%$ of patients experienced complete remission after induction. In previously untreated patients, there was a trend to better CR rate after TA $(14 / 19,74 \%)$ compared to FLAG/CLARA $(4 / 6,67 \%$; $P=.08)$. Two patients underwent allogeneic hematopoietic stem-cell transplantation. Two CR patients (1 in each group) (14.3\%) underwent to allogeneic hematopoietic stem-cell transplantation. The median OS was only 9.7 months, thereby highlighting the poor outcome of patients with cardiac comorbidities (Figure 1). In line with the higher response rate, patients treated with TA had a trend to higher median [range] EFS (8.6 [5.5-11.8] months vs. 1.4 [0.9-1.9] months in TA and FLAG/ CLARA subgroups, respectively, $P=.06$ ) (Figure 2).

The CR rate in patients with R/R AML was $11(50 \%)$ of 22 , with $1(25 \%)$ of 4 in the TA group versus $10(56 \%)$ of 18 in the FLAG/CLARA group $(P=.27)$. Among patients who experienced $\mathrm{CR}, 7$ underwent autologous stem-cell transplantation, including $1(100 \%)$ of 1 in the TA group and $6(60 \%)$ of 10 in the FLAG/CLARA group. Median OS and EFS were, respectively, 9.7 and 3 months. Given the small number of patients $(n=4)$ treated with TA, comparisons between the two treatment groups were not performed.

\section{Discussion}

We evaluated the safety and efficacy results of 3 different chemotherapy regimens (TA, FLAG, or CLARA) used as an alternative to anthracycline-containing regimens for patients with AML who had a contraindication to the use of anthracyclins. Our results show that these regimens are safe, with nonrelapse mortality at 5 years of $12.5 \%$ and $1.9 \%$ for TA and FLAG/CLARA, respectively $(P=.59)$, and a $21 \%$ rate of cardiovascular events. Results also confirm the efficacy of these regimens in this specific patient population, with CR rates of $63 \%$ and $50 \%$ for previously untreated and R/R AML, respectively.

Anthracycline exposure is associated with both acute cardiomyopathy and chronic cardiac complications (especially heart failure), depending on the cumulative dose. Cardiotoxicity after receipt of anthracyclines is typically associated with loss of myocardial mass, leading to progressive cardiac remodeling and dysfunction. ${ }^{9}$ In mice, doxorubicin exposure impaired vascular development, resulting in abnormal vascular architecture in the heart with less branching and decreased capillary density. ${ }^{10}$ In a study of 1807 cancer survivors treated with anthracyclines and followed for 7 years, Ning and $\mathrm{al}^{11}$ found that $33 \%$ died of heart disease. Cardiac imaging revealed that the estimated incidence of heart failure was
$5 \%, 26 \%$, and $48 \%$ at 400,550 , and $700 \mathrm{mg} / \mathrm{m}^{2}$ of anthracycline, respectively. ${ }^{12}$

Several regimens that do not contain anthracyclines have been developed. They typically combine cytarabine with another drug, such as etoposide, topotecan, nucleoside analogs (fludarabine, clofarabine), or gemtuzumab ozogamicin. These regimens may represent an alternative for treatment of patients with contraindication to anthracyclines, but they have been poorly studied in this context.

The 3 regimens we studied were associated with acceptable toxicity. Tolerance of the TA regimen was better, with fewer AEs: $4(18 \%)$ in the TA group versus $14(50 \%)$ in the FLAG/CLARA group $(P=.001)$. We found less hematologic toxicity; incidence and duration of neutropenia was similar between the groups $(P=.62)$, but duration of thrombocytopenia was significantly shorter in TA group $(P=.03)$. However, these differences must be interpreted cautiously because the patients populations are not similar.

There was no difference in terms of global cardiovascular toxicity between the 2 treatment groups $(7 / 28,25 \%$, after FLAG/CLARA, and $4 / 24,17 \%$, after TA). In the literature, we found lower rates of cardiac toxicity with these regimens-almost no toxicity with $\mathrm{TA}^{13}$ and FLAG, ${ }^{14}$ and around $10 \%$ for CLARA. ${ }^{3}$

In terms of clinical efficacy, the results of our study are consistent with previously published data. In newly diagnosed patients, the $C R$ rate after TA therapy was $59 \%$, with a median EFS of 36 months and a median OS of 41 months. ${ }^{15}$ However, it is worth noting that the EFS and OS in our study were substantially shorter, thus highlighting the poor prognosis of patients with secondary AML.

$\mathrm{R} / \mathrm{R}$ patients had a CR rate of $36.4 \%$ (4/11), time to progression of 16 weeks, and median OS at 32 weeks. ${ }^{13}$

The majority (65\%) of our patients in the CLARA/FLAG group had R/R AML. Median time to relapse was short (4.5 months) in patients treated in the CLARA/FLAG group and may have an impact on the observed outcome. In this group, the outcome was worse compared to the TA group but compared favorably with previous studies using these 2 regimens in a comparable patient population. Indeed, CLARA showed a $33 \% \mathrm{CR}$, a median diseasefree survival of 5.7 months, and a median OS of 6.6 months, ${ }^{16}$ and FLAG showed $65 \%$ CR, median EFS of 4 months, and median OS of 8.5 months. ${ }^{14}$

Some alternative treatments can also be considered in these patients. Gemtuzumab ozogamicin, a humanized anti-CD33 monoclonal antibody linked to calicheamicin, has resulted in unfit AML a CR rate of $8.1 \%(C R+C R$ with incomplete hematologic recovery, $24.3 \%$ ), with an early toxic mortality of $7.2 \%$ and one heart failure. ${ }^{17}$ The median disease-free survival was 5.3 months, the 1 -year OS $24.3 \%$, and the 2 -year OS $<10 \% .{ }^{17}$ Finally, patients aged 61 to 75 years with adverse cytogenetics benefit less from treatment. ${ }^{18}$ The main reason was $27.9 \%$ of cardiac AEs, with only $6.3 \%$ grade $3 / 4 \mathrm{AE} .{ }^{17}$ Compared to our population, with median age of 68 years and $38.5 \%$ of subjects with adverse ELN-risk AML, we think that gemtuzumab ozogamicin had a bad benefit/risk ratio. A combination of hypomethylating agents and venetoclax showed promising results in unfit AML patients in first-line treatment. The CR rate was $67 \%$ and the median OS 17.5 months. In patients with poor cytogenetic risk AML, the CR rate was $60 \%$, but the median duration of CR was 7 months and the median OS was 9.6 months. Decitabine provided for 10 days has been also studied in unfit AML 


\section{Cardiac Contraindication to Anthracyclines}

patients. For CR, CR with incomplete platelet recovery, and CR with incomplete hematologic recovery, the rate was $40 \%$, median duration of $\mathrm{CR}$ was 6 months, and 1-year OS was $25 \%$. These strategies might be discussed in this specific population, but the safety profiles of these combinations is difficult to address.

\section{Conclusion}

Our retrospective study showed that TA, FLAG, and CLARA regimens work well in AML patients with cardiac comorbidities who are ineligible for the classical $3+7$ regimen. However, this patient population represents a high-risk group for which new alternative regimens not only devoid of cardiac toxicity but also associated with reduced overall toxicity should be developed.

\section{Clinical Practice Points}

- Regimens used to treat patients with contraindications to anthracyclines are different between centers and between physicians at the same center. Indeed, there is no standard treatment, perhaps because this entity is so rare. However, these cases are classical and must be studied.

- Topotecan, clofarabine, and fludarabine are well-known drugs that have been used for years. TA, CLARA, and FLAG were efficient regimens in patients with poor outcomes.

- We found a trend to better EFS in the TA group, with fewer AEs in these patients. This may help clinicians in practice.

\section{Disclosure}

The authors have stated that they have no conflict of interest.

\section{References} 1. Löwenberg B, Ossenkoppele GJ, van Putten W, et al. High-dose daunorubicin in
older parients with acute mycloid leukemia. N Engl J Med 2009; 361:1235-48. 2. Clavio M, Gatto S, Beltrami G, et al. Fludarabine, ARA-C, idarubicin and G2. Clavio M, Gatto S, Beltrami G, et al. Fludarabine, ARA-C, idarubicin and G-
CSF (FLAG-Ida), high dose ARA-C and early stem cell transplant. A feasable and effective therapeutic strategy for de novo AML patients. $J$ Exp Clin Cancer Res 2002; $21: 481-7$.

3. Bumett AK, Russell NH, Kdl J, et al. European development of clofarabine as treatment for older parients with acute myeloid leukemia considered unsuitable for intensive chemotherapy. J Clin Oncol 2010; 28:2389-95.

4. Kantarjian HM, Erba HP, Claxton D, et al. Phase II study of clofarabine monotherapy in previously untreated older adults with acute myeloid leukenia and unfavorable prognostic factors. J Clin Oncol 2010; 28:549-55.

5. Kadia TM, Faderl S, Ravandi F, et al. Final results of a phase 2 trial of clofarabine and low-dose cytarabine altemating with decitabine in older parients with newly diagnosed acute mydoid leukemia. Cancer 2015; 121:2375-82.

6. Vey N, Kantarjian H, Beran M, et al. Combination of topotecan with cytarabine Vey N, Kantarjian $\mathrm{H}$, Beran M, et al. Combination of topotecan with cytarabine
or etoposide in parients with refractory or rdapsed acute myeloid leukemia: results of a randomized phase I/II study. Invest New Drugs 1999; 17:89-95.

7. Prébet T, Jean E, Autret A, ce al. Combination of cytarabine and topotecan in patients treated for acute myeloid leukemia with persistent disease after frontline induction. Leuk Lymphoma 2012; 53:2186-91.

8. Dohner H, Estey E, Grimwade D, et al. Diagnosis and management of AML in adults: 2017 ELN recommendations from an international expert pand. Blood 2017; 1 29:424-47.

9. Swain SM, Whaley FS, Ewer MS. Congestive heart failure in patients treated with doxorubicin: a retrospective analysis of three trials. Cancer 2003; 97: 2869-79.

10. Aleman BM, Moser EC, Nuver J, et al. Cardiovascular disease after cancer therapy, EJC Suppl 2014; 12:18-28.

11. Ning Y, Shen Q, Herrick $\mathrm{K}$, et al. Cause of death in cancer survivors Cancer Res 2012:72, LB-339.

12. Huang C, Zhang X, Ramil JM, et al. Juvenile exposure to anthracyclines impairs cardiac progenitor cell function and vasaularization resulting in greater suscoptibility to stress-induced myocardial injury in adult mice. Circulation 2010; 121: 675-83.

13. Weihrauch MR, Staib P, Scibcrlich B, et al. Phase I/II clinical study of topotecan and cytarabine in patients with myelodysplastic syndrome, dironic myelomonoand cytarabine in patents with myelodysplastic syndrome, dronic myelomono-

14. Vulaj V, Perissinotti AJ, Uebel JR, et al. The FOSSIL study: FLAG or standard 7 +3 induction therapy in secondary acute myeloid laukemia. Letue Res 2018; 70: 91-6.

15. Estey EH, Thall PF, Cortes JE, ot al. Comparison of idarubicin + ara-C-, fludarabine + ara- $\mathrm{C}-$, and topotecan + ara-C-based regimens in treatment of newly diagnosed acute myeloid leukemia, refractory anemia with excess blasts in transformation, or refractory anemia with excess blasts. Blood 2001; 98:3575-83.

16. Fadel S, Wetzler M, Rizzieri D, et al. Clofarabine plus cytarabine compared with cytarabine alone in older patients with rdapsed or refractory acute myelogenous leukemia: results from the CLASSIC I trial. J Cin Oncol 2012; 30:2492-9.

17. Amadori S, Suciu S, Selleslag D, et al. Gemtuzumab ozogamicin versus best supportive care in older patients with newly diagnosed acute myeloid lenkemia unsuitable for intensive chemotherapy: results of the randomized phase III EORTC-GIMEMA AML-19 trial. J Clin Oned 2016; 34:972-9.

18. Burnett AK, Hills RK, Milligan D, a al. Identification of parients with aate myeloblastic leukemia who benefit from the addition of gemtuzumab ozogamicin: results of the MRC AML15 trial. J Clin Oncol 2011; 29:369-77. 


\section{DISCUSSION}

Notre étude cherchait à évaluer la tolérance et l'efficacité de trois protocoles de chimiothérapie différents (TA et FLAG/CLARA) en alternative au protocole d'induction classique par $3+7$ pour les patients atteints de LAM avec une contre-indication aux anthracyclines. Nous avons montré que ces traitements étaient peu toxiques, avec une NRM à 5 ans de $17,9 \%$ et $12,5 \%$ dans les groupes FLAG/CLARA et TA respectivement $(p=0,59)$ et $21,2 \%$ d'événements cardiovasculaires tous grades confondus. Notre étude a également permis de confirmer l'efficacité de ces traitements, avec des taux de RC de $63 \%$ pour les patients nouvellement diagnostiqués et de $50 \%$ pour les patients réfractaires ou en rechute (résultat non publiés) dont le pronostic est connu comme catastrophique.

La toxicité aux anthracyclines a été étudiée depuis de nombreuses années. On sait qu'elle est associée avec à la fois des cardiomyopathies aiguës et des complications cardiaques chroniques notamment de l'insuffisance cardiaque, dans les deux cas avec une relation de dose-intensité une fois la dose maximale cumulée dépassée. La cardiotoxicité après traitement par anthracyclines est classiquement associée avec une diminution de la masse musculaire myocardique menant progressivement à un remodelage cardiaque avec notamment une dilatation des cavités cardiaques (cardiomyopathie dilatée) et des dysfonctions ${ }^{13}$. Chez la souris, l'exposition à la Doxorubicine a montré des altérations de la néovascularisation ce qui résultait en une architecture vasculaire cardiaque anormale avec moins de ramifications et un réseau capillaire avec une densité moindre ${ }^{14}$. Dans une étude sur 1807 patients ayant survécu à un cancer et traités par anthracyclines, avec un suivi de sept ans, Ning et al. ont trouvé que $33 \%$ des patients sont décédés suites à une pathologie cardiaque ${ }^{15}$. Les études d'imagerie cardiaque retrouvaient une incidence estimée d'insuffisance cardiaque de 5\%, 26\% et $48 \%$ aux doses de 400,550 et $700 \mathrm{mg} / \mathrm{m}^{2}$, respectivement ${ }^{16}$. C'est après ces constations que différents protocoles sans anthracyclines ont commencé à être utilisés. Ils comprenaient généralement de l'Aracytine associée à une autre drogue: Etoposide, Topotecan, analogues nucléosidiques (Fludarabine, Clofarabine), Gemtuzumab Ozogamicine. Ces protocoles représentent une vraie alternative pour ces patients avec comorbidités cardiaques mais ont été très peu étudiés dans ce contexte.

Cependant, l'évaluation de protocoles est nécessaire devant la gravité de ces patients. Notre étude retrouvait, en effet, dans les résultats que nous avons choisi de ne pas publier, une survie cumulée globale de 9,8 mois $[1,1-22,1]$ dans le groupe FLAG/CLARA et de 10,2 mois $[1,1-19,2]$ dans le groupe TA. Ces résultats sont comparables à ceux retrouvés dans la littérature. En termes d'efficacité, dans la cohorte globale, on ne retrouvait pas de différence significative en termes de RC (71,4\% vs $62,5 \%)$ ni de survie globale cumulée $(p=0,59)$. La survie sans rechute censurée à la date de l'allogreffe était significativement plus longue dans le groupe traité par TA que par FLAG/CLARA (16,1 mois vs 4,7 mois, 
$p=0,001)$. Même si cette différence n'était pas significative, il se peut que le bénéfice obtenu en termes de RC soit suffisant pour induire la différence constatée en termes de RFS. L'analyse multivariée retrouvait également un bénéfice en termes de survie cumulée sans rechute censurée à l'allogreffe pour le protocole TA par rapport au FLAG/CLARA dans les sous-groupes des patients nouvellement diagnostiqués $(16,1$ vs 5,9 mois, $p=0,03)$ et des patients de risque défavorable selon la classification de l'ELN $(17,8$ vs 4,1 mois, $p=0,006)$.

Du fait du hasard dans la constitution des groupes, nous avons constaté que les deux groupes n'était pas similaires du point de vue du statut de la maladie $(p=0,002)$. En effet, on retrouvait que $83,3 \%$ des patients étaient nouvellement diagnostiqués dans le groupe TA contre seulement $35,7 \%$ dans le groupe FLAG/CLARA. Compte tenu de l'influence connue du statut de la maladie sur le pronostic nous avons décidé d'éliminer ce facteur confondant en étudiant plus particulièrement le sous-groupe des patients nouvellement diagnostiqués.

Dans les LAM nouvellement diagnostiquées, éligibles à la chimiothérapie intensive, le taux de RC attendu après traitement par TA était de 59\%, avec une survie sans événement de 36 mois et une survie globale médiane de 41 mois $^{17}$. Même si dans notre étude nous avons obtenus un meilleur taux de $\mathrm{RC}$ les résultats de survie étaient considérablement plus courts, ce qui illustre bien le pronostic très défavorable de ces patients comorbides. Malgré le peu de patients inclus dans ce sous-groupe d'étude, on retrouvait une tendance pour une meilleure efficacité du TA par rapport au FLAG/CLARA en termes de RFS $(p=0,06)$, ce qui apparait comme un indicateur d'un avantage possible à l'utilisation de ce protocole dans cette population. Dans les LAM en rechute ou réfractaires, le taux de RC attendu était de $36,4 \%$, la durée médiane de réponse était de onze semaines et la survie globale des patients avec un syndrome myélodysplasique ou une LAM était de 32 semaines $^{18}$. Le groupe de patients en rechute ou réfractaires traités par TA dans notre étude est difficilement comparable vu qu'il ne comprenait que quatre patients, cependant, les résultats de survie paraissent encore sensiblement inférieurs à ceux attendus dans la population générale.

Les patients traités par CLARA ou FLAG étaient majoritairement des patients en rechute ou réfractaire de leur LAM. Le temps médian avant la rechute était court chez les patients traités par FLAG/CLARA (4,5 mois) ce qui a pu avoir un impact sur les résultats de survie observés. En effet, ce traitement semble être utilisable en « bridge to transplant » devant un nombre important de patients mis en RC $(71,4 \%)$ mais une rechute précoce ; cependant, du fait de leurs comorbidités, la plupart des patients de notre cohorte ont été récusés à l'allogreffe de CSH. Dans le sous-groupe des patients $R / R$, le devenir de ces patients traités par FLAG/CLARA était moins bon que les patients traités par TA mais nos résultats étaient par contre globalement supérieurs à ceux retrouvés dans la littérature pour une 
population comparable. En effet, le protocole CLARA avait montré $33 \%$ de taux de RC, une médiane de survie sans maladie à 5,7 mois et une survie globale médiane de 6,6 mois $^{19}$. Le protocole FLAG a, quant à lui, montré un taux de RC de $65 \%$ avec une EFS de quatre mois et une survie globale de 8,5 mois ${ }^{20}$.

D’autres protocoles peuvent encore être envisagés chez ces patients. Le Gemtuzumab Ozogamicine, un anticorps monoclonal humanisé anti-CD33 lié à la Calichéamicine, un antibiotique semi-synthétique avec des propriétés cytotoxiques, a montré un taux de RC de $8,1 \%$ dans les LAM non éligibles à la chimiothérapie intensive (" unfit ») avec un taux de $\mathrm{RC}+\mathrm{RCi}$ à $24,3 \%$ et une mortalité toxique précoce de 7,2\% avec une insuffisance cardiaque ${ }^{21}$. La RFS médiane était de 5,3 mois et la survie globale à un an de $24,3 \%$ et à deux ans, inférieure à $10 \%{ }^{21}$. Cependant, les patients âgés de 61 à 75 ans avec une cytogénétique défavorable bénéficiaient le moins de ce traitement ${ }^{22}$. La raison majeure pour cela était $27,9 \%$ d'El cardiovasculaires dont seulement $6,3 \%$ de grade trois ou quatre ${ }^{21}$.

En comparant à notre cohorte, dans laquelle l'âge médian était 68 ans et où 38,5\% des patients étaient de pronostic cytogénétique défavorable selon la classification ELN, nous pensons que l'utilisation de Gemtuzumab Ozogamicine aurait une eu balance bénéfice-risque défavorable.

D'autre part, l'association d'agents hypométhylants avec du Venetoclax, un inhibiteur de Bcl-2, a montré des résultats prometteurs chez les patients unfit en première ligne de traitement pour une LAM. Le taux de RC était de $67 \%$ et la survie globale médiane était de 17,5 mois. Chez les patients de pronostic cytogénétique défavorable, le taux de RC était de $60 \%$ mais la durée médiane de persistance de la RC était de sept mois et la survie globale de 9,6 mois. De plus, dans cette étude, les patients avec une pathologie cardiovasculaire avec un score New York Heart Association (NYHA) $\geq 2$ ou un antécédent de maladie cardiovasculaire décrite comme pouvant affecter négativement leur participation à l'étude étaient exclus ${ }^{22}$ ce qui rend difficile l'évaluation de cette association dans notre population d'intérêt. De plus, cette étude a observé de nombreux arrêts de traitements (70\%) dont les raisons principales étaient la progression mais aussi de la toxicité (événements indésirables non liés à la progression). Une autre étude évaluait l'association Venetoclax et LDAC (faibles doses d'Aracytine à $20 \mathrm{mg} / \mathrm{m}^{2} /$ jour) chez les patients unfit à la chimiothérapie intensive pour une LAM nouvellement diagnostiquée. Dans les maladies de novo ils obtenaient 45\% de RC mais dans les LAM secondaires avec un caryotype de fait plus défavorable, seulement $5 \%$ de RC. L'âge médian des patients était de $74 a n s$ et $32 \%$ des patients avaient un pronostic cytogénétique défavorable. La durée médiane de réponse était de 8,1 mois et la survie globale médiane 10,1 mois ${ }^{23}$.

La Décitabine, un agent hypométhylant, administrée pendant dix jours a également été étudiée chez les patients unfit atteints de LAM. Le taux de RC et RCi était de 40\%, la durée médiane de RC était de 
six mois et la survie globale à un an était de $25 \%$ ou une survie globale médiane à 8.1 mois $^{24}$. Ces stratégies peuvent être discutées pour cette population spécifiquement mais les profils de toxicité de ces combinaisons sont difficiles à évaluer.

Enfin, nous avons établi que ces trois protocoles étaient acceptables du point de vue de la toxicité induite avec des NRM de 17,9 et 12,5\% pour les protocoles FLAG/CLARA et TA respectivement $(p=0,59)$. La tolérance du protocole TA semblait cependant supérieure avec une incidence moindre $d^{\prime} E I: 50 \%(n=14)$ dans le groupe FLAG/CLARA versus $18 \%(n=4)$ dans le groupe TA, $p=0,001$. Nous avons également retrouvé une toxicité hématologique moindre dans le groupe TA, avec une durée de thrombopénie moins longue (24,1 versus 36,1 jours, $p=0,03)$. La durée de neutropénie profonde semblait également moins longue dans le groupe TA (26 versus 38 jours), sans que ces résultats ne soient significatifs. Enfin, nous n'avons pas retrouvé de différence significative en terme d'événements cardiovasculaires ( $17 \%$ pour le groupe TA, $25 \%$ pour le groupe FLAG/CLARA). Dans la littérature, les taux de toxicité cardiaque retrouvés avec ces protocoles étaient inférieurs (presque aucune pour les protocoles $\mathrm{TA}^{18}$ et $\mathrm{FLAG}^{20}$, et autour de $10 \%$ pour le protocole CLARA ${ }^{25}$. Cette différence peut être expliquée par le fait que notre recueil a compris les événements cardiovasculaires de tous grades et non pas que les grades 3 et 4 et d'autre part, par les comorbidités spécifiques à notre population. Enfin, l'interprétation de ces différences doit être faite avec précautions devant les différences entre les groupes.

\section{CONCLUSION}

Notre étude rétrospective et pragmatique a montré que les protocoles TA, FLAG et CLARA avaient une efficacité convenable chez les patients atteints de LAM et porteurs de comorbidités cardiaques, inéligibles au $3+7$ classique. Cependant, cette population représente un groupe de risque très défavorable pour laquelle de nouveaux protocoles devraient être évalués afin d'améliorer l'efficacité en termes de survie et de réduire la toxicité globale mais aussi cardiaque. 


\section{REFERENCES}

1. Sanz MA, lacoboni $G$, Montesinos $P$, Venditti A. Emerging strategies for the treatment of older patients with acute myeloid leukemia. Ann Hematol. 2016;95(10):1583-1593. doi:10.1007/s00277-016-2666-2

2. Mrozek K, Bloomfield CD. Chromosome aberrations, gene mutations and expression changes, and prognosis in adult acute myeloid leukemia. Hematology Am Soc Hematol Educ Program. 2006:169-177. doi:10.1182/asheducation-2006.1.169

3. Dohner H, Estey E, Grimwade D, et al. Diagnosis and management of AML in adults: 2017 ELN recommendations from an international expert panel. Blood. 2017;129(4):424-447. doi:10.1182/blood-2016-08-733196

4. Sanz MA, Grimwade D, Tallman MS, et al. Management of acute promyelocytic leukemia: recommendations from an expert panel on behalf of the European LeukemiaNet. Blood. 2009;113(9):1875-1891. doi:10.1182/blood-2008-04-150250

5. Ofran Y, Tallman MS, Rowe JM. How I treat acute myeloid leukemia presenting with preexisting comorbidities. Blood. 2016;128(4):488-496. doi:10.1182/blood-2016-01-635060

6. Ho AD, Schetelig J, Bochtler T, et al. Allogeneic Stem Cell Transplantation Improves Survival in Patients with Acute Myeloid Leukemia Characterized by a High Allelic Ratio of Mutant FLT3-ITD. Biol Blood Marrow Transplant. 2016;22(3):462-469. doi:10.1016/j.bbmt.2015.10.023

7. Lowenberg B, Ossenkoppele GJ, van Putten W, et al. High-dose daunorubicin in older patients with acute myeloid leukemia. N Engl J Med. 2009;361(13):1235-1248. doi:10.1056/NEJMoa0901409

8. Westhus J, Noppeney R, Duhrsen U, Hanoun M. FLAG salvage therapy combined with idarubicin in relapsed/refractory acute myeloid leukemia. Leuk Lymphoma. 2019;60(4):1014-1022. doi:10.1080/10428194.2018.1508670

9. Kim H, Lee J-H, Joo Y-D, et al. A prospective, multicenter phase Il study of continuous infusion of FLAG for patients older than $60 \mathrm{yr}$ with resistant acute myeloid leukemia: a comparison with intensive younger patients' trial. Eur J Haematol. 2016;96(2):188-197. doi:10.1111/ejh.12568

10. Kantarjian HM, Erba HP, Claxton D, et al. Phase Il study of clofarabine monotherapy in previously untreated older adults with acute myeloid leukemia and unfavorable prognostic factors. J Clin Oncol. 2010;28(4):549-555. doi:10.1200/JCO.2009.23.3130

11. Kadia TM, Faderl S, Ravandi F, et al. Final results of a phase 2 trial of clofarabine and low-dose cytarabine alternating with decitabine in older patients with newly diagnosed acute myeloid leukemia. Cancer. 2015;121(14):2375-2382. doi:10.1002/cncr.29367

12. Prebet $\mathrm{T}$, Jean $\mathrm{E}$, Autret $\mathrm{A}$, et al. Combination of cytarabine and topotecan in patients treated for acute myeloid leukemia with persistent disease after frontline induction. Leuk Lymphoma. 2012;53(11):2186-2191. doi:10.3109/10428194.2012.685733

13. Swain SM, Whaley FS, Ewer MS. Congestive heart failure in patients treated with doxorubicin: a retrospective analysis of three trials. Cancer. 2003;97(11):2869-2879. doi:10.1002/cncr.11407 
14. Aleman BMP, Moser EC, Nuver J, et al. Cardiovascular disease after cancer therapy. EJC Suppl. 2014;12(1):18-28. doi:10.1016/j.ejcsup.2014.03.002

15. Ning Y, Shen Q, Herrick K, et al. Abstract LB-339: Cause of death in cancer survivors. Cancer Res. 2012;72(8 Supplement):LB-339. doi:10.1158/1538-7445.AM2012-LB-339

16. Huang $\mathrm{C}$, Zhang $\mathrm{X}$, Ramil JM, et al. Juvenile exposure to anthracyclines impairs cardiac progenitor cell function and vascularization resulting in greater susceptibility to stress-induced myocardial injury in adult mice. Circulation. 2010;121(5):675-683.

doi:10.1161/CIRCULATIONAHA.109.902221

17. Estey EH, Thall PF, Cortes JE, et al. Comparison of idarubicin + ara-C-, fludarabine + ara-C-, and topotecan + ara-C-based regimens in treatment of newly diagnosed acute myeloid leukemia, refractory anemia with excess blasts in transformation, or refractory anemia with excess blasts. Blood. 2001;98(13):3575-3583. doi:10.1182/blood.v98.13.3575

18. Weihrauch MR, Staib P, Seiberlich B, Hoffmann M, Diehl V, Tesch H. Phase I/II clinical study of topotecan and cytarabine in patients with myelodysplastic syndrome, chronic myelomonocytic leukemia and acute myeloid leukemia. Leuk Lymphoma. 2004;45(4):699-704. doi:10.1080/10428190310001593175

19. Faderl S, Wetzler M, Rizzieri D, et al. Clofarabine plus cytarabine compared with cytarabine alone in older patients with relapsed or refractory acute myelogenous leukemia: results from the CLASSIC I Trial. J Clin Oncol. 2012;30(20):2492-2499. doi:10.1200/JCO.2011.37.9743

20. Vulaj V, Perissinotti AJ, Uebel JR, et al. The FOSSIL Study: FLAG or standard 7+3 induction therapy in secondary acute myeloid leukemia. Leuk Res. 2018;70:91-96.

doi:10.1016/j.leukres.2018.05.011

21. Amadori S, Suciu S, Selleslag D, et al. Gemtuzumab Ozogamicin Versus Best Supportive Care in Older Patients With Newly Diagnosed Acute Myeloid Leukemia Unsuitable for Intensive Chemotherapy: Results of the Randomized Phase III EORTC-GIMEMA AML-19 Trial. J Clin Oncol. 2016;34(9):972-979. doi:10.1200/JCO.2015.64.0060

22. DiNardo CD, Pratz K, Pullarkat V, et al. Venetoclax combined with decitabine or azacitidine in treatment-naive, elderly patients with acute myeloid leukemia. Blood. 2019;133(1):7-17. doi:10.1182/blood-2018-08-868752

23. Wei AH, Strickland SAJ, Hou J-Z, et al. Venetoclax Combined With Low-Dose Cytarabine for Previously Untreated Patients With Acute Myeloid Leukemia: Results From a Phase Ib/II Study. J Clin Oncol. 2019;37(15):1277-1284. doi:10.1200/JCO.18.01600

24. He P-F, Zhou J-D, Yao D-M, et al. Efficacy and safety of decitabine in treatment of elderly patients with acute myeloid leukemia: A systematic review and meta-analysis. Oncotarget. 2017;8(25):41498-41507. doi:10.18632/oncotarget.17241

25. Burnett AK, Russell NH, Kell J, et al. European development of clofarabine as treatment for older patients with acute myeloid leukemia considered unsuitable for intensive chemotherapy. J Clin Oncol. 2010;28(14):2389-2395. doi:10.1200/JCO.2009.26.4242 


\section{ANNEXES}

Annexe 1- Définition des critères de réponse dans les LAM selon ELN 2017

\begin{tabular}{|c|c|c|}
\hline Category & Definition & Comment \\
\hline \multicolumn{3}{|l|}{ Response } \\
\hline $\begin{array}{l}\text { CR without minimal } \\
\text { residual disease } \\
\text { (CRRR-) }\end{array}$ & If studied pretreatment, $C R$ with negativity for a genetic marker by $R T-q P C R$, or $C R$ with negativity by MFC & $\begin{array}{l}\text { Sensitivities vary by marker tested, and by method used; therefore, test } \\
\text { used and sensitivity of the assay should be reported; analyses should be } \\
\text { done in experienced laboratories (centralized diagnostics) }\end{array}$ \\
\hline $\begin{array}{l}\text { Complete remission } \\
\text { (CR) }\end{array}$ & $\begin{array}{l}\text { Bone marrow blasts }<5 \% \text {; absence of circulating blasts and blasts with Auer rods; absence of extramedullary } \\
\text { disease; } A N C \geq 1.0 \times 10^{9} / \mathrm{L}(1000 / \mu \mathrm{L}) \text {; platelet count } \geq 100 \times 10^{9} / \mathrm{L}(100000 / \mu \mathrm{L})\end{array}$ & $\mathrm{MRD}^{+}$or unknown \\
\hline $\begin{array}{l}\text { CR with incomplete } \\
\text { hematologic recovery } \\
\left(\mathrm{CR}_{\mathrm{i}}\right)\end{array}$ & $\begin{array}{l}\text { All CR criteria except for residual neutropenia }\left(<1.0 \times 10^{9} / \mathrm{L}[1000 / \mu \mathrm{L}]\right) \text { or thrombocytopenia }\left(<100 \times 10^{9} / \mathrm{L}\right. \\
[100000 / \mu \mathrm{L}])\end{array}$ & \\
\hline $\begin{array}{l}\text { Morphologic } \\
\text { leukemia-free state } \\
\text { (MLFS) }\end{array}$ & $\begin{array}{l}\text { Bone marrow blasts }<5 \% \text {; absence of blasts with Auer rods; absence of extramedullary disease; no hematologic } \\
\text { recovery required }\end{array}$ & $\begin{array}{l}\text { Marrow should not merely be "aplastic"; at least } 200 \text { cells should be } \\
\text { enumerated or cellularity should be at least } 10 \%\end{array}$ \\
\hline $\begin{array}{l}\text { Partial remission } \\
\text { (PR) }\end{array}$ & $\begin{array}{l}\text { All hematologic criteria of } \mathrm{CR} \text {; decrease of bone marrow blast percentage to } 5 \% \text { to } 25 \% \text {; and decrease of } \\
\text { pretreatment bone marrow blast percentage by at least } 50 \%\end{array}$ & Especially important in the context of phase $1-2$ clinical trials \\
\hline \multicolumn{3}{|l|}{ Treatment failure } \\
\hline $\begin{array}{l}\text { Primary refractory } \\
\text { disease }\end{array}$ & $\begin{array}{l}\text { No } \mathrm{CR} \text { or } \mathrm{CR}_{\mathrm{i}} \text { after } 2 \text { courses of intensive induction treatment; excluding patients with death in aplasia or death } \\
\text { due to indeterminate cause }\end{array}$ & $\begin{array}{l}\text { Regimens containing higher doses of cytarabine (see Table } 8 \text { ) are } \\
\text { generally considered as the best option for patients not responding to a } \\
\text { first cycle of } 7+3 \text {; the likelihood of responding to such regimens is lower } \\
\text { after failure of a first }\end{array}$ \\
\hline Death in aplasia & $\begin{array}{l}\text { Deaths occurring } \geq 7 \mathrm{~d} \text { following completion of initial treatment while cytopenic; with an aplastic or } \\
\text { hypoplastic bone marrow obtained within } 7 \mathrm{~d} \text { of death, without evidence of persistent leukemia }\end{array}$ & \\
\hline $\begin{array}{l}\text { Death from } \\
\text { indeterminate cause }\end{array}$ & $\begin{array}{l}\text { Deaths occurring before completion of therapy, or }<7 \mathrm{~d} \text { following its completion; or deaths occurring } \geq 7 \mathrm{~d} \\
\text { following completion of initial therapy with no blasts in the blood, but no bone marrow examination available }\end{array}$ & \\
\hline \multicolumn{3}{|l|}{$\begin{array}{l}\text { Response criteria for } \\
\text { clinical trials only }\end{array}$} \\
\hline Stable disease & Absence of $\mathrm{CR}_{\mathrm{MRD}-}, \mathrm{CR}, \mathrm{CR}_{\mathrm{i}}, \mathrm{PR}, \mathrm{MLFS}$; and criteria for $\mathrm{PD}$ not met & Period of stable disease should last at least $3 \mathrm{mo}$ \\
\hline \multirow[t]{5}{*}{$\begin{array}{l}\text { Progressive disease } \\
(\mathrm{PD})^{*}= \pm\end{array}$} & Evidence for an increase in bone marrow blast percentage and or increase of absolute blast counts in the blood: & $\begin{array}{l}\text { Category mainly applies for older patient given low-intensity or single- } \\
\text { agent "targeted therapies" in clinical trials }\end{array}$ \\
\hline & $\begin{array}{l}->50 \% \text { increase in marrow blasts over baseline (a minimum } 15 \% \text { point increase is required in cases with }<30 \% \\
\text { blasts at baseline; or persistent marrow blast percentage of }>70 \% \text { over at least } 3 \text { mo; without at least a } 100 \% \\
\text { improvement in ANC to an absolute level }\left(>0.5 \times 10^{9} / \mathrm{L}[500 / \mu \mathrm{L}] \text {, and or platelet count to }>50 \times 10^{9} / \mathrm{L}[50\right. \\
000 / \mu \mathrm{L}] \text { nontransfused); or }\end{array}$ & In general, at least 2 cycles of a novel agent should be administered \\
\hline & $\begin{array}{l}\cdot>50 \% \text { increase in peripheral blasts }(\mathrm{WBC} \times \% \text { blasts }) \text { to }>25 \times 10^{9} / \mathrm{L}(>25000 / \mu \mathrm{L}) \text { (in the absence of } \\
\text { differentiation syndrome })^{ \pm} \text {, or }\end{array}$ & $\begin{array}{l}\text { Some protocols may require blast increase in } 2 \text { consecutive marrow } \\
\text { assessments at least } 4 \text { wk apart; the date of progression should then be } \\
\text { defined as of the first observation date }\end{array}$ \\
\hline & - New extramedullary disease & $\begin{array}{l}\text { Some protocols may allow transient addition of hydroxyurea to lower } \\
\text { blast counts }\end{array}$ \\
\hline & & $\begin{array}{l}\text { "Progressive disease" is usually accompanied by a decline in ANC and } \\
\text { platelets and increased transfusion requirement and decline in } \\
\text { performance status or increase in symptoms }\end{array}$ \\
\hline \multicolumn{3}{|l|}{ Relapse } \\
\hline $\begin{array}{l}\text { Hematologic relapse } \\
\text { (after } \mathrm{CR}_{\mathrm{MRD}-\text { - }} \mathrm{CR} \text {, } \\
\left.\mathrm{CR}_{\mathrm{i}}\right)\end{array}$ & Bone marrow blasts $\geq 5 \%$; or reappearance of blasts in the blood; or development of extramedullary disease & \\
\hline $\begin{array}{l}\text { Molecular relapse } \\
\text { (after } C R_{\text {MRD- }} \text { ) }\end{array}$ & If studied pretreatment, reoccurrence of MRD as assessed by RT-qPCR or by MFC & $\begin{array}{l}\text { Test applied, sensitivity of the assay, and cutoff values used must be } \\
\text { reported; analyses should be done in experienced laboratories } \\
\text { (centralized diagnostics) }\end{array}$ \\
\hline
\end{tabular}

ANC, absolute neutrophil count; IDH, isocitrate dehydrogenase; MLFS, morphologic leukemia-free state; WBC, white blood cell. 
Annexe 2 - Critères de classification des événements indésirables (CTCAE version 5), section

\section{Maladies du sang et du système lymphatique.}

\begin{tabular}{|c|c|c|c|c|c|}
\hline \multicolumn{6}{|c|}{ Blood and lymphatic system disorders } \\
\hline CTCAE Term & Grade 1 & Grade 2 & Grade 3 & Grade 4 & Grade 5 \\
\hline Anemia & $\begin{array}{l}\text { Hemoglobin }(\mathrm{Hgb})<L L \mathrm{~N}-10.0 \\
\mathrm{~g} / \mathrm{dL} ;<\mathrm{LLN}-6.2 \mathrm{mmol} / \mathrm{L} ;<L L \mathrm{~N} \\
-100 \mathrm{~g} / \mathrm{L}\end{array}$ & $\begin{array}{l}\mathrm{Hgb}<10.0-8.0 \mathrm{~g} / \mathrm{dL} ;<6.2-4.9 \\
\mathrm{mmol} / \mathrm{L} ;<100-80 \mathrm{~g} / \mathrm{L}\end{array}$ & $\begin{array}{l}\mathrm{Hgb}<8.0 \mathrm{~g} / \mathrm{dL} ;<4.9 \mathrm{mmol} / \mathrm{L} ; \\
<80 \mathrm{~g} / \mathrm{L} ; \text { transfusion indicated }\end{array}$ & $\begin{array}{l}\text { Life-threatening } \\
\text { consequences; urgent } \\
\text { intervention indicated }\end{array}$ & Death \\
\hline \multicolumn{6}{|c|}{$\begin{array}{l}\text { Definition: A disorder characterized by a reduction in the amount of hemoglobin in } 100 \mathrm{ml} \text { of blood. Signs and symptoms of anemia may include pallor of the skin and mucous } \\
\text { membranes, shortness of breath, palpitations of the heart, soft systolic murmurs, lethargy, and fatigability. } \\
\text { Navigational Note: - }\end{array}$} \\
\hline Bone marrow hypocellular & $\begin{array}{l}\text { Mildly hypocellular or }<=25 \% \\
\text { reduction from normal } \\
\text { cellularity for age }\end{array}$ & $\begin{array}{l}\text { Moderately hypocellular or } \\
>25-<50 \% \text { reduction from } \\
\text { normal cellularity for age }\end{array}$ & $\begin{array}{l}\text { Severely hypocellular or }>50- \\
<=75 \% \text { reduction cellularity } \\
\text { from normal for age }\end{array}$ & $\begin{array}{l}\text { Aplastic persistent for longer } \\
\text { than } 2 \text { weeks }\end{array}$ & Death \\
\hline \multicolumn{6}{|c|}{$\begin{array}{l}\text { Definition: A disorder characterized by the inability of the bone marrow to produce hematopoietic elements. } \\
\text { Navigational Note: - }\end{array}$} \\
\hline $\begin{array}{l}\text { Disseminated intravascular } \\
\text { coagulation }\end{array}$ & - & $\begin{array}{l}\text { Laboratory findings with no } \\
\text { bleeding }\end{array}$ & $\begin{array}{l}\text { Laboratory findings and } \\
\text { bleeding }\end{array}$ & $\begin{array}{l}\text { Life-threatening } \\
\text { consequences; urgent } \\
\text { intervention indicated }\end{array}$ & Death \\
\hline \multirow{2}{*}{\multicolumn{6}{|c|}{$\begin{array}{l}\text { Definition: A disorder characterized by systemic pathological activation of blood clotting mechanisms which results in clot formation throughout the body. There is an increase in the } \\
\text { risk of hemorrhage as the body is depleted of platelets and coagulation factors. } \\
\text { Navigational Note: - }\end{array}$}} \\
\hline & & & & & \\
\hline Eosinophilia & $>U L N$ and >Baseline & - & Steroids initiated & - & - \\
\hline \multicolumn{6}{|c|}{$\begin{array}{l}\text { Definition: A disorder characterized by laboratory test results that indicate an increased number of eosinophils in the blood. } \\
\text { Navigational Note: - }\end{array}$} \\
\hline Febrile neutropenia & - & - & $\begin{array}{l}\text { ANC }<1000 / \mathrm{mm} 3 \text { with a single } \\
\text { temperature of }>38.3 \text { degrees } \\
\mathrm{C}(101 \text { degrees } \mathrm{F}) \text { or a } \\
\text { sustained temperature of } \\
>=38 \text { degrees } \mathrm{C}(100.4 \\
\text { degrees } \mathrm{F}) \text { for more than one } \\
\text { hour }\end{array}$ & $\begin{array}{l}\text { Life-threatening } \\
\text { consequences; urgent } \\
\text { intervention indicated }\end{array}$ & Death \\
\hline \multirow{2}{*}{\multicolumn{6}{|c|}{$\begin{array}{l}\text { Definition: A disorder characterized by an ANC }<1000 / \mathrm{mm} 3 \text { and a single temperature of }>38.3 \text { degrees C (101 degrees F) or a sustained temperature of }>=38 \text { degrees C ( } 100.4 \text { degrees } \\
\text { F) for more than one hour. } \\
\text { Navigational Note: - }\end{array}$}} \\
\hline & & & & & \\
\hline Hemolysis & $\begin{array}{l}\text { Laboratory evidence of } \\
\text { hemolysis only (e.g., direct } \\
\text { antiglobulin test; DAT; } \\
\text { Coombs'; schistocytes; } \\
\text { decreased haptoglobin) }\end{array}$ & $\begin{array}{l}\text { Evidence of hemolysis and } \\
>=2 \mathrm{~g} \text { decrease in hemoglobin }\end{array}$ & $\begin{array}{l}\text { Transfusion or medical } \\
\text { intervention indicated (e.g., } \\
\text { steroids) }\end{array}$ & $\begin{array}{l}\text { Life-threatening } \\
\text { consequences; urgent } \\
\text { intervention indicated }\end{array}$ & Death \\
\hline
\end{tabular}

Navigational Note: -

\begin{tabular}{|c|c|c|c|c|c|}
\hline \multicolumn{6}{|c|}{ Blood and lymphatic system disorders } \\
\hline CTCAE Term & Grade 1 & Grade 2 & Grade 3 & Grade 4 & Grade 5 \\
\hline Hemolytic uremic syndrome & - & - & $\begin{array}{l}\text { Laboratory findings with } \\
\text { clinical consequences (e.g., } \\
\text { renal insufficiency, petechiae) }\end{array}$ & $\begin{array}{l}\text { Life-threatening } \\
\text { consequences, (e.g., CNS } \\
\text { hemorrhage or } \\
\text { thrombosis/embolism or renal } \\
\text { failure) }\end{array}$ & Death \\
\hline \multicolumn{6}{|c|}{$\begin{array}{l}\text { Definition: A disorder characterized by a form of thrombotic microangiopathy with renal failure, hemolytic anemia, and severe thrombocytopenia. } \\
\text { Navigational Note: - }\end{array}$} \\
\hline Leukocytosis & - & - & $>100,000 / \mathrm{mm} 3$ & $\begin{array}{l}\text { Clinical manifestations of } \\
\text { leucostasis; urgent } \\
\text { intervention indicated }\end{array}$ & Death \\
\hline \multicolumn{6}{|c|}{$\begin{array}{l}\text { Definition: A disorder characterized by laboratory test results that indicate an increased number of white blood cells in the blood. } \\
\text { Navigational Note: - }\end{array}$} \\
\hline Lymph node pain & Mild pain & $\begin{array}{l}\text { Moderate pain; limiting } \\
\text { instrumental ADL }\end{array}$ & $\begin{array}{l}\text { Severe pain; limiting self care } \\
\text { ADL }\end{array}$ & - & - \\
\hline \multicolumn{6}{|c|}{$\begin{array}{l}\text { Definition: A disorder characterized by a sensation of marked discomfort in a lymph node. } \\
\text { Navigational Note: - }\end{array}$} \\
\hline Methemoglobinemia & - & $>$ ULN & Requiring urgent intervention & Life-threatening consequences & Death \\
\hline \multicolumn{6}{|c|}{$\begin{array}{l}\text { Definition: A disorder characterized by laboratory test results that indicate increased methemoglobin in the blood. } \\
\text { Navigational Note: - }\end{array}$} \\
\hline $\begin{array}{l}\text { Thrombotic } \\
\text { thrombocytopenic purpura }\end{array}$ & - & - & $\begin{array}{l}\text { Laboratory findings with } \\
\text { clinical consequences (e.g., } \\
\text { renal insufficiency, petechiae) }\end{array}$ & $\begin{array}{l}\text { Life-threatening } \\
\text { consequences, (e.g., CNS } \\
\text { hemorrhage or } \\
\text { thrombosis/embolism or renal } \\
\text { failure) }\end{array}$ & Death \\
\hline \multicolumn{6}{|c|}{$\begin{array}{l}\text { Definition: A disorder characterized by the presence of microangiopathic hemolytic anemia, thrombocytopenic purpura, fever, renal abnormalities and neurological abnormalities such } \\
\text { as seizures, hemiplegia, and visual disturbances. It is an acute or subacute condition. } \\
\text { Navigational Note: - }\end{array}$} \\
\hline $\begin{array}{l}\text { Blood and lymphatic system } \\
\text { disorders - Other, specify }\end{array}$ & $\begin{array}{l}\text { Asymptomatic or mild } \\
\text { symptoms; clinical or } \\
\text { diagnostic observations only; } \\
\text { intervention not indicated }\end{array}$ & $\begin{array}{l}\text { Moderate; minimal, local or } \\
\text { noninvasive intervention } \\
\text { indicated; limiting age- } \\
\text { appropriate instrumental ADL }\end{array}$ & $\begin{array}{l}\text { Severe or medically significant } \\
\text { but not immediately life- } \\
\text { threatening; hospitalization or } \\
\text { prolongation of existing } \\
\text { hospitalization indicated; } \\
\text { limiting self care ADL }\end{array}$ & $\begin{array}{l}\text { Life-threatening } \\
\text { consequences; urgent } \\
\text { intervention indicated }\end{array}$ & Death \\
\hline
\end{tabular}


Annexe 3 - Définition des critères d'évaluation pronostique selon ELN 2017

\begin{tabular}{|c|c|}
\hline Category & Definition \\
\hline Overall survival & $\begin{array}{l}\text { Defined for all patients of a trial; measured from the date of entry into a clinical trial or from } \\
\text { the date of diagnosis (eg, for correlative science studies) to the date of death from any cause; } \\
\text { patients not known to have died at last follow-up are censored on the date they were last } \\
\text { known to be alive }\end{array}$ \\
\hline $\begin{array}{l}\text { Relapse-free } \\
\text { survival (RFS) }{ }^{*}{ }^{\dagger}\end{array}$ & $\begin{array}{l}\text { Defined only for patients achieving } \mathrm{CR} \text {, or } \mathrm{CR}_{\mathrm{i}} \text {; measured from the date of achievement of a } \\
\text { remission until the date of relapse or death from any cause; patients not known to have } \\
\text { relapsed or died at last follow-up are censored on the date they were last examined }\end{array}$ \\
\hline $\begin{array}{l}\text { Event-free survival } \\
(\mathrm{EFS})^{\dagger}\end{array}$ & $\begin{array}{l}\text { Defined for all patients of a trial; measured from the date of entry into a study to the date of } \\
\text { primary refractory disease, or relapse from } \mathrm{CR} \text {, or } \mathrm{CR}_{\mathrm{i}} \text {, or death from any cause; patients not } \\
\text { known to have any of these events are censored on the date they were last examined }\end{array}$ \\
\hline $\begin{array}{l}\text { Cumulative } \\
\text { incidence of relapse } \\
(\mathrm{CIR})^{\dagger}+\end{array}$ & $\begin{array}{l}\text { Defined for all patients achieving } \mathrm{CR}, \mathrm{CR}_{\mathrm{i}} \text {; measured from the date of achievement of a } \\
\text { remission until the date of relapse; patients not known to have relapsed are censored on the } \\
\text { date they were last examined; patients who died without relapse are counted as a competing } \\
\text { cause of failure }\end{array}$ \\
\hline
\end{tabular}

Open in a separate window

$\mathrm{CID}$, cumulative incidence of death; CIR, cumulative incidence of relapse.

"RFS and disease-free survival have been used with the same definition.

In clinical trials in which the response criterion $\mathrm{CR}_{\mathrm{MRD}}$ - is used, consideration should be given to include molecular relapse as assessed by RT-qPCR or MFC as a criterion for relapse; similarly, for analysis of EFS, no achievement of $\mathrm{CR}_{\text {MRD- }}$ may be regarded as an event. The definitions of RFS, EFS, and CIR must be clearly defined within each protocol.

-It is important to provide estimates of CID as well because just considering the results of CIR may be misleading if, for instance, CIR is lower for 1 group but CID is actually higher for that same group. 


\section{Serment d'Hippocrate}

Au moment d'être admis à exercer la médecine, je promets et je jure d'être fidèle aux lois de l'honneur et de la probité.

Mon premier souci sera de rétablir, de préserver ou de promouvoir la santé dans tous ses éléments, physiques et mentaux, individuels et sociaux.

Je respecterai toutes les personnes, leur autonomie et leur volonté, sans aucune discrimination selon leur état ou leurs convictions. J'interviendrai pour les protéger si elles sont affaiblies, vulnérables ou menacées dans leur intégrité ou leur dignité. Même sous la contrainte, je ne ferai pas usage de mes connaissances contre les lois de l'humanité.

J'informerai les patients des décisions envisagées, de leurs raisons et de leurs conséquences. Je ne tromperai jamais leur confiance et n'exploiterai pas le pouvoir hérité des circonstances pour forcer les consciences.

Je donnerai mes soins à l'indigent et à quiconque me les demandera. Je ne me laisserai pas influencer par la soif du gain ou la recherche de la gloire.

Admis dans l'intimité des personnes, je tairai les secrets qui me seront confiés. Reçu à l'intérieur des maisons, je respecterai les secrets des foyers et ma conduite ne servira pas à corrompre les mœurs. Je ferai tout pour soulager les souffrances. Je ne prolongerai pas abusivement les agonies. Je ne provoquerai jamais la mort délibérément.

Je préserverai l'indépendance nécessaire à l'accomplissement de ma mission. Je n'entreprendrai rien qui dépasse mes compétences. Je les entretiendrai et les perfectionnerai pour assurer au mieux les services qui me seront demandés.

J'apporterai mon aide à mes confrères ainsi qu'à leurs familles dans l'adversité.

Que les hommes et mes confrères m'accordent leur estime si je suis fidèle à mes promesses ; que je sois déshonoré et méprisé si j’y manque. 